\title{
An Entry to Stable Mixed Phosphine-Osmium-NHC Polyhydrides
}

\author{
María L. Buil, ${ }^{\dagger}$ Juan J. F. Cardo ${ }^{\dagger}$ Miguel A. Esteruelas, ${ }^{*}{ }^{\dagger}$ Israel Fernández, ${ }^{\dagger}$ and Enrique Oñate ${ }^{\dagger}$ \\ †Departamento de Química Inorgánica, Instituto de Síntesis Química y Catálisis Homogénea (ISQCH), Centro de Innovación \\ en Química Avanzada (ORFEO-CINQA),Universidad de Zaragoza-CSIC, 50009 Zaragoza, Spain \\ *Departamento de Química Orgánica I, Facultad de Ciencias Químicas, Centro de Innovación en Química Avanzada \\ (ORFEO-CINQA), Universidad Complutense de Madrid, 28040 Madrid, Spain \\ Supporting Information Placeholder
}

\begin{abstract}
An entry to mixed phosphine-osmium-NHC polyhydride complexes is described, starting from the five-coordinate hydrido-alkylidyne compounds $\left[\mathrm{OsHCl}(\equiv \mathrm{CPh})(\mathrm{IPr})\left(\mathrm{PR}_{3}\right)\right] \mathrm{OTf}\left(\mathrm{IPr}=1,3\right.$-bis $\left(2,6\right.$-disopropylphenyl)imidazolylidene. $\mathrm{OTf}=\mathrm{CF}_{3} \mathrm{SO}_{3}$. $\left.\mathrm{PR}_{3}=\mathrm{P}^{i} \mathrm{Pr}_{3}(\mathbf{1}), \mathrm{PPh}_{3}(\mathbf{2})\right)$. The experimental procedure involves the borylation of the Os-C triple bond of $\mathbf{1}$ and $\mathbf{2}$ with $\mathrm{NaBH}_{4}$ and the subsequent alcoholysis of the borylation products $\mathrm{OsH}_{2} \mathrm{Cl}\left(\eta^{2}-\mathrm{H}-\mathrm{BCH}_{2} \mathrm{Ph}\right)(\mathrm{IPr})\left(\mathrm{PR}_{3}\right)\left(\mathrm{PR}_{3}=\mathrm{P}^{i} \mathrm{Pr}_{3} \quad(\mathbf{3}), \mathrm{PPh}_{3}\right.$ (4)) or $\mathrm{OsH}_{2}\left(\eta^{2}: \eta^{2}: \mathrm{H}_{2} \mathrm{BCH}_{2} \mathrm{Ph}\right)(\mathrm{IPr})\left(\mathrm{P}^{i} \mathrm{Pr}_{3}\right)$ (5). Stirring of $\mathbf{3}$ in 2-propanol affords the five coordinate chloride-trihydride $\mathrm{OsH}_{3} \mathrm{Cl}(\mathrm{IPr})\left(\mathrm{P}^{i} \mathrm{Pr}_{3}\right)_{2}$ (6), which reacts with $\mathrm{NaBH}_{4}$ to give $\mathrm{OsH}_{3}\left(\kappa^{2}-\mathrm{H}_{2} \mathrm{BH}_{2}\right)(\mathrm{IPr})\left(\mathrm{P}^{i} \mathrm{Pr}_{3}\right)(7)$. This trihydride-tetrahydrideborate derivative and its $\mathrm{PPh}_{3}$-counterpart $\mathrm{OsH}_{3}\left(\kappa^{2}-\mathrm{H}_{2} \mathrm{BH}_{2}\right)(\mathrm{IPr})\left(\mathrm{PPh}_{3}\right)(\mathbf{8})$ can be also obtained in a one-pot procedure, starting from 1 and 2 and using methanol at $-60^{\circ} \mathrm{C}$ instead of 2-propanol as alcoholysis agent. The bonding situation in $\mathbf{7}$ and $\mathbf{8}$, analyzed by DFT calculations using AIM and NBO methods, resembles that found in $\mathrm{B}_{2} \mathrm{H}_{6}$ and contrasts with the bonding situation in the bis- $\sigma$-borane derivative 5. Stirring of 7 and $\mathbf{8}$ in 2-propanol leads to the corresponding $d^{2}$-hexahydride derivatives $\operatorname{OsH}_{6}(\operatorname{Ir})\left(\mathrm{PR}_{3}\right)\left(\mathrm{PR}_{3}=\mathrm{P}^{i} \mathrm{Pr}_{3}(\mathbf{9})\right.$, $\mathrm{PPh}_{3}(\mathbf{1 0})$ ), which reduce the $\mathrm{C} \equiv \mathrm{N}$ triple bond of benzonitrile and promote the subsequent chelate-assisted ortho-CH bond activation of the resulting phenylmethanimine, to form the trihydride compounds $\mathrm{OsH}_{3}\left\{\kappa^{2}-N, C-\left(\mathrm{NH}=\mathrm{CH}-\mathrm{C}_{6} \mathrm{H}_{4}\right)\right\}\left(\mathrm{IPr}^{2}\right)\left(\mathrm{PR}_{3}\right)_{2}\left(\mathrm{PR}_{3}=\mathrm{P}^{i} \mathrm{Pr}{ }_{3}\right.$ (11), $\mathrm{PPh}_{3}(\mathbf{1 2})$ ), containing an stabilized orthometalated aldimine.
\end{abstract}

\section{INTRODUCTION}

The chemistry of polyhydride complexes of platinum group metals is a field under permanent development. Unlike other more mature areas, it offers new exciting conceptual challenges and at the same time the possibility of interacting with different fields, including conversion and storage of regenerative energy, ${ }^{1}$ functionalization of hydrocarbons, ${ }^{2}$ drugs design, ${ }^{3}$ or the preparation of new types of compounds with notable applications in material science. ${ }^{4}$ This versatility is a consequence of the ability of these compounds to activate a wide range of $\sigma$-bonds. In this respect, osmium is a privileged element because of its centered position in the periodic table at the third row.

The M-H bond is among the strongest metal-ligand bonds. ${ }^{5}$ Despite of its strength, the hydride ligand shows a great mobility. ${ }^{6}$ In agreement with this, polyhydrides complexes undergo combined movements of the hydrogen atom bound to the metal center. These position exchanges are thermally activated and take place with activation barriers which are lower than those involved in the movements of the heavy ligands defining the skeleton of the polyhydrides. ${ }^{7}$

Mass, basicity, geometry, rigidity and size of the co-ligands are factors that determine the geometry of the skeleton and the reactivity of the polyhydrides. According to the nature of the co-ligands, the polyhydrides of platinum group metals can be classified $^{8}$ into bis(phosphine) compounds, complexes with tripodal phosphines, half-sandwich derivatives, complexes with trispyrazolylborate and related groups, and species with pincer ligands. Although the N-heterocyclic carbenes (NHCs) have proven to be excellent ligands in coordination chemistry ${ }^{9}$ and promising results during the past few years underline a great potential of their transition metal complexes in catalysis ${ }^{10}$ and several fields of material science, ${ }^{11}$ polyhydride complexes of platinum group metals with NHC ligands in their skeleton are extremely rare. Most of them are bis(phosphine) ${ }^{12}$ or half-sandwhich ${ }^{13}$ derivatives that contain an additional NHC ligand. Only in a few cases the NHC ligand is a fundamental element of the structure of the polyhydride. Macgregor, Pregosin, Whittlesey and co-workers have reported that the tetrakis(NHC) cation $\left[\mathrm{RuH}\left(\mathrm{IMe}_{4}\right)_{4}\right]^{+}$coordinates $\mathrm{H}_{2}$ to afford the trans-hydride-dihydrogen $\left[\mathrm{RuH}\left(\eta^{2}-\right.\right.$ $\left.\left.\mathrm{H}_{2}\right)\left(\mathrm{IMe}_{4}\right)_{4}\right]^{+}\left(\mathrm{IMe}_{4}=1,3,4,5\right.$-tetramethylimidazol-2-ylidene $) .{ }^{14}$ Conejero, Lledós, and co-workers have shown that the cationic species $\quad\left[\mathrm{Pt}\left(\mathrm{NHC}^{\prime}\right)(\mathrm{NHC})\right]^{+} \quad(\mathrm{NHC}=1,3-\mathrm{bis}(2,6-$ diisopropylphenyl)imidazole-2-ylidene (IPr); 1,3-dimethyl4,5-dimethylimidazol-2-ylidene (IMes*)), containing a cyclometalated NHC ligand (NHC'), undergo hydrogenolysis to afford the monohydrides $\left[\mathrm{PtH}(\mathrm{NHC})_{2}\right]^{+}$in equilibrium with the trans-hydride-dihydrogen derivatives $\left[\mathrm{PtH}\left(\eta^{2}-\right.\right.$ $\left.\left.\mathrm{H}_{2}\right)(\mathrm{NHC})_{2}\right]^{+} .{ }^{15}$ Leitner and co-workers have observed that $1,3-$ dimethylimidazol-2-ylidene (IMes) displaces phosphine of $\mathrm{RuH}_{2}\left(\eta^{2}-\mathrm{H}_{2}\right)_{2}\left(\mathrm{PCy}_{3}\right)_{2}$ to give the mixed phosphine-NHC dihydride-bis(dihydrogen) $\mathrm{RuH}_{2}\left(\eta^{2}-\mathrm{H}_{2}\right)_{2}(\mathrm{IMes})\left(\mathrm{PCy}_{3}\right)$. The double substitution to form the bis(NHC) counterpart $\mathrm{RuH}_{2}\left(\eta^{2}\right.$ $\left.\mathrm{H}_{2}\right)_{2}$ (IMes) $)_{2}$ only occurs in very small amount. ${ }^{16}$ Some dihydrides have been also known. ${ }^{17}$ 
The preparation of mixed or heterolytic complexes with different ligands of similar characteristics but complementary properties, such as phosphine-metal-NHC, is challenging because of their strong tendency to undergo distribution reactions. ${ }^{18}$ During our catalytic studies on osmium-promoted C-C and $\mathrm{C}$-heteroatom coupling reactions, ${ }^{19}$ we observed that the NHC-complex $\left[\left(\eta^{6}-p\right.\right.$-cymene $\left.) \mathrm{OsCl}(=\mathrm{CHPh})(\mathrm{IPr})\right] \mathrm{OTf}(\mathrm{OTf}=$ $\mathrm{CF}_{3} \mathrm{SO}_{3}$ ) easily loses the arene. ${ }^{20}$ The resulting metal fragment can be trapped with phosphines to form the five-coordinate derivatives $\left[\mathrm{OsHCl}(\equiv \mathrm{CPh})(\mathrm{IPr})\left(\mathrm{PR}_{3}\right)\right] \mathrm{OTf}\left(\mathrm{PR}_{3}=\mathrm{P}^{i} \mathrm{Pr}_{3}(\mathbf{1})\right.$, $\left.\mathrm{PPh}_{3}(2)\right){ }^{21}$ which allows us to develop new chemistry. Thus, borylation reactions of the metal-carbon triple bond have been recently achieved without affecting the $\mathrm{R}_{3} \mathrm{P}-\mathrm{Os}-\mathrm{IPr}$ skeleton. The reactions afforded both borinium, $\mathrm{OsH}_{2} \mathrm{Cl}\left(\eta^{2}-\mathrm{H}-\right.$ $\left.\mathrm{BCH}_{2} \mathrm{Ph}\right)(\mathrm{IPr})\left(\mathrm{PR}_{3}\right)\left(\mathrm{PR}_{3}=\mathrm{P}^{i} \mathrm{Pr}_{3}(3), \mathrm{PPh}_{3}(4)\right),{ }^{22}$ and bis- $\sigma-$ borane, $\mathrm{OsH}_{2}\left(\eta^{2} ; \eta^{2}-\mathrm{H}_{2} \mathrm{BCH} \mathrm{CH}_{2} \mathrm{Ph}\right)(\mathrm{IPr})\left(\mathrm{P}^{\mathrm{i}} \mathrm{Pr}_{3}\right)^{23}(\mathbf{5})$, derivatives (Scheme 1). In the search for mixed $\mathrm{R}_{3} \mathrm{P}-\mathrm{Os}-\mathrm{NHC}$ polyhydrides, we have now carried out the borylation reactions under alcoholysis conditions, in view of the oxophilic character of both boron-ligands.

This paper shows the first entry to $\mathrm{R}_{3} \mathrm{P}-\mathrm{Os}-\mathrm{NHC}$ polyhydrides complexes, which are relevant from a conceptual point of view because they demonstrate that is possible to stabilize polyhydrides with a mixed L-M-L' skeleton, when the L and L' ligands have complementary properties, and are useful because they can be used as starting materials for the preparation of other hydride derivatives.

\section{Scheme 1}

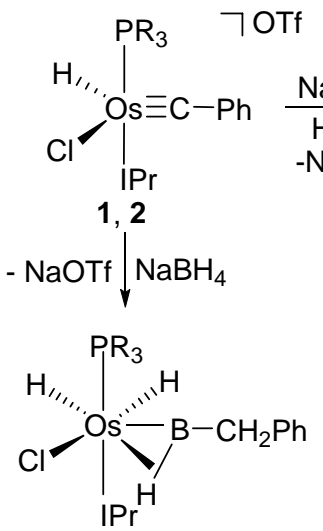

3,4

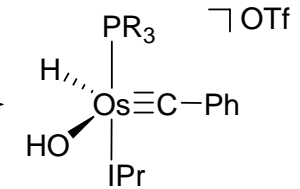

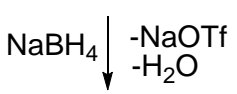

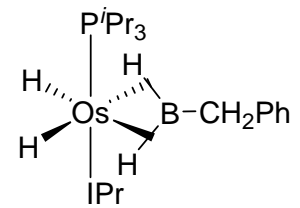

5

$$
\mathrm{PR}_{3}=\mathrm{P}^{i} \mathrm{Pr}_{3}(\mathbf{1}, \mathbf{3}), \mathrm{PPh}_{3}(\mathbf{2}, \mathbf{4})
$$

\section{RESULTS AND DISCUSION}

1. Formation of a six-coordinate chloro-trihydrideosmium(IV) complex. Previous EDA-NOCV calculations have revealed that the main contribution to the interaction between the borinium ligand of $\mathbf{3}$ and the square pyramidal metal fragment is the electrostatic term, which contributes about $57 \%$ to the total interaction energy. ${ }^{22}$ As a result, the osmium-borinium bond has a high degree of polarization, which is consistent with the high electronegativity of the osmium atom and suggests a significant positive partial charge on the ligand. ${ }^{24}$ In agreement with this, the borinium group undergoes alcoholysis. In 2-propanol under reflux, the addition of the $\mathrm{O}-\mathrm{H}$ bond of the alcohol to the Os-B bond of 3 affords the red, six-coordinate, chloride-trihydride-
osmium(IV) complex $\mathrm{OsH}_{3} \mathrm{Cl}(\mathrm{IPr})\left(\mathrm{P}^{i} \mathrm{Pr}_{3}\right)$ (6) in quantitative yield, after $4 \mathrm{~h}$ (eq 1).

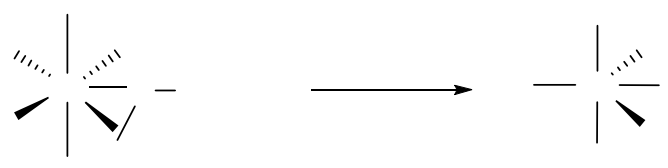

Complex 6 has been characterized by X-ray diffraction analysis. Figure 1 shows a view of the molecular geometry. The structure has essentially $C s$ symmetry with the phosphine and NHC ligands trans disposed $\left(\mathrm{C}(1)\right.$-Os- $\left.\mathrm{P}=171.41(15)^{\circ}\right)$ and the chloride, the metal center, and the hydrides lying in the perpendicular plane to the $\mathrm{C}(1)$-Os-P direction. The most noticeable feature of the complex is the $\mathrm{H}(01)-\mathrm{Os}-\mathrm{H}(02)$ and $\mathrm{H}(02)-\mathrm{Os}-\mathrm{H}(03)$ angles of $73(3)^{\circ}$, which markedly deviate from $90^{\circ}$. The structure resembles those of the bis(phosphine) derivates $\mathrm{OsH}_{3} \mathrm{X}\left(\mathrm{PR}_{3}\right)_{2}\left(\mathrm{PR}_{3}=\mathrm{P}^{t} \mathrm{Bu}_{2} \mathrm{Me} ; \mathrm{X}=\mathrm{Cl} . \mathrm{PR}_{3}=\mathrm{P}^{\mathrm{i}} \mathrm{Pr}_{3}\right.$; $\mathrm{X}=\mathrm{Cl}, \mathrm{Br}, \mathrm{I}),{ }^{25} \mathrm{OsH}_{3}\left(\mathrm{OR}_{\mathrm{F}}\right)\left(\mathrm{P}^{i} \mathrm{Pr}_{3}\right)_{2}\left(\mathrm{OR}_{\mathrm{F}}=\mathrm{OCH}_{2} \mathrm{CF}_{3}\right.$, $\left.\mathrm{OCH}\left(\mathrm{CF}_{3}\right)_{2}\right),{ }^{26}, \mathrm{OsH}_{3}(\mathrm{OPh})\left(\mathrm{P}^{i} \mathrm{Pr}_{3}\right)_{2}{ }^{27} \quad$ and $\mathrm{OsH}(\mathrm{Bcat})_{2} \mathrm{Cl}\left(\mathrm{P}^{i} \mathrm{Pr}_{3}\right)_{2}{ }^{28}$ The octahedral geometry is not favorable for these compounds. They undergo distortion that destabilizes one orbital from the $\mathrm{t}_{2 \mathrm{~g}}$ set and simultaneously stabilizes the occupied ones to be diamagnetic. The distortion partially cancels the electron deficiency at the metal, which receives additional electron density from the $\pi$-donor group. ${ }^{25-28}$

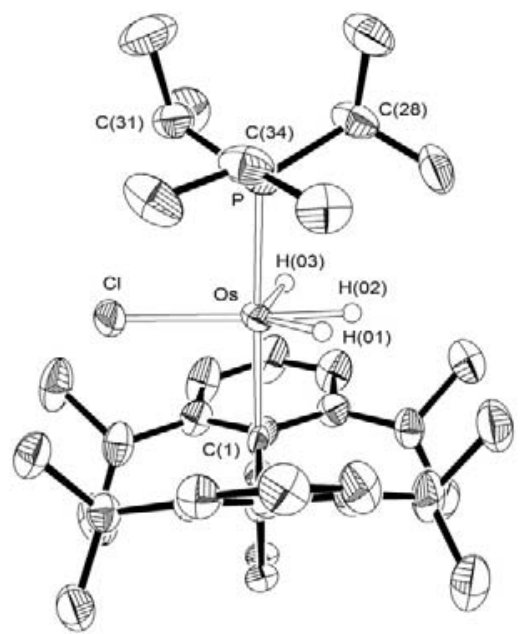

Figure 1. Molecular diagram of 6. Selected bond lengths $(\AA)$ and angles (deg): Os- $\mathrm{Cl}=2.4245(16)$, Os-P $=2.3310(13)$, Os$\mathrm{C}(1)=2.068(5) ; \mathrm{C}(1)-\mathrm{Os}-\mathrm{P}=171.41(15), \mathrm{H}(01)-\mathrm{Os}-\mathrm{Cl}=$ $125(2), \mathrm{H}(03)-\mathrm{Os}-\mathrm{Cl}=90(2), \mathrm{H}(01)-\mathrm{Os}-\mathrm{H}(02)=73(3)$, $\mathrm{H}(02)-O s-\mathrm{H}(03)=73(3)$. Displacement ellipsoids are given at the $50 \%$ probability level.

The ${ }^{1} \mathrm{H},{ }^{13} \mathrm{C}\left\{{ }^{1} \mathrm{H}\right\}$ and ${ }^{31} \mathrm{P}\left\{{ }^{1} \mathrm{H}\right\}$ NMR spectra of $\mathbf{6}$ in toluene- $d_{8}$ are consistent with the structure shown in Figure 1. Thus, the hydride ligands display an $\mathrm{AB}_{2}$ spin system in the ${ }^{1} \mathrm{H}\left\{{ }^{31} \mathrm{P}\right\}$ NMR spectrum. The $\mathrm{AB}_{2}$ pattern, $\delta_{\mathrm{A}}-15.16$ and $\delta_{\mathrm{B}}-21.17$ is distinguished by the magnitude of the $J_{\mathrm{AB}}$ value of $290 \mathrm{~Hz}$ at $90^{\circ} \mathrm{C}$, which supports quantum exchange coupling. At room temperature, the resonance corresponding to the metalated carbene carbon atom appears at $170.0 \mathrm{ppm}$, as a doublet with a C-P coupling constant of $74 \mathrm{~Hz}$, in the ${ }^{13} \mathrm{C}\left\{{ }^{1} \mathrm{H}\right\}$ NMR spectrum. At the same temperature, the ${ }^{31} \mathrm{P}\left\{{ }^{1} \mathrm{H}\right\}$ NMR spectrum shows a singlet at $47.7 \mathrm{ppm}$. 
2. Trihydride-tetrahydridoborate-osmium(IV) and hexahydride-osmium(VI) complexes. Treatment of a tetrahydrofuran solution of 6 with 1.5 equiv of $\mathrm{NaBH}_{4}$, at $-40^{\circ} \mathrm{C}$, for 15 min produces the replacement of the chloride ligand by the tetrahydroborate group, to afford the trihydridetetrahydroborate-osmium(IV) derivative $\mathrm{OsH}_{3}\left(\kappa^{2}-\right.$ $\left.\mathrm{H}_{2} \mathrm{BH}_{2}\right)(\mathrm{IPr})\left(\mathrm{P}^{i} \mathrm{Pr}_{3}\right)(7)$ which was isolated as a yellow solid in $44 \%$ yield (eq 2); i.e., $20 \%$ with regard to the hydridealkylidyne 1. Complex 7 and its triphenylphosphine counterpart $\mathrm{OsH}_{3}\left(\kappa^{2}-\mathrm{H}_{2} \mathrm{BH}_{2}\right)(\mathrm{IPr})\left(\mathrm{PPh}_{3}\right)(\mathbf{8})$ can be also obtained in a one-pot synthesis procedure, starting from the respective hydride-alkylidyne complexes $\mathbf{1}$ and 2, when methanol instead 2propanol is used at $-60^{\circ} \mathrm{C}$ as alcoholysis agent of the borinium intermediates 3 and 4 . Under these conditions, both yellow trihydride-tetrahydrideborate derivatives were isolated in about 30\% global yield (eq 3). Complexes $\mathbf{7}$ and $\mathbf{8}$ are notable because constitute the first mixed $\mathrm{R}_{3} \mathrm{P}-\mathrm{M}-\mathrm{NHC}$ tetrahydrideborate compounds in the osmium chemistry. The known tetrahydrideborate complexes of this element are limited to bis(phosphine) species. They include the osmium(II) derivatives $\mathrm{OsH}\left(\kappa^{2}-\mathrm{H}_{2} \mathrm{BH}_{2}\right)(\mathrm{CO})\left(\mathrm{PR}_{3}\right)_{2}\left(\mathrm{PR}_{3}=\mathrm{P}^{i} \mathrm{Pr}_{3}, \mathrm{P}^{\mathrm{t}} \mathrm{Bu}_{2} \mathrm{Me}\right)^{29}$ and $\mathrm{Os}\left(\mathrm{BR}_{2}\right)\left(\kappa^{2}-\mathrm{H}_{2} \mathrm{BH}_{2}\right)(\mathrm{CO})\left(\mathrm{P}^{i} \mathrm{Pr}_{3}\right)_{2}\left(\mathrm{BR}_{2}=\mathrm{Bcat}, \mathrm{Bpin}\right)^{30}$ and the osmium(IV) compounds $\mathrm{OsH}_{3}\left(\kappa^{2}-\mathrm{H}_{2} \mathrm{BH}_{2}\right)\left(\mathrm{PR}_{3}\right)_{2} \quad\left(\mathrm{PR}_{3}=\right.$ $\mathrm{P}^{i} \mathrm{Pr}_{3}{ }^{31}, \mathrm{P}^{i} \mathrm{Pr}_{2} \mathrm{Ph}, \mathrm{PCy}_{3}{ }^{32}$, which have been prepared by replacement of $[\mathrm{Cl}]^{-}$by $\left[\mathrm{BH}_{4}\right]^{-29,31}$ substitution of $\mathrm{HB}(\mathrm{OR})_{2}$ by $\mathrm{BH}_{3}$ from coordinated dihydridoborate groups, ${ }^{30}$ and addition of $\mathrm{BH}_{3}$ to unsaturated hydride compounds. ${ }^{32}$

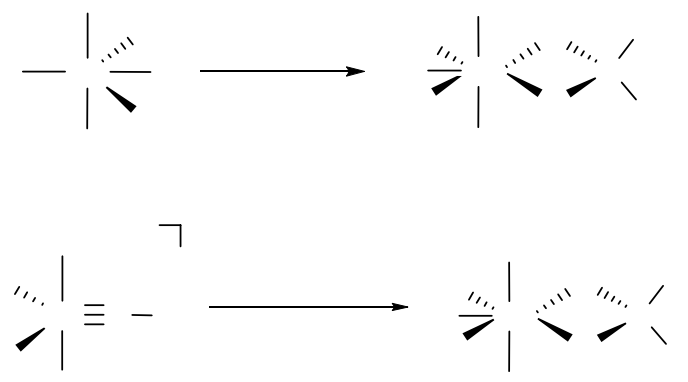

The formation of $\mathbf{7}$ and $\mathbf{8}$ was confirmed by means of the Xray structure of $\mathbf{8}$ (Figure 2), which proves the $\kappa^{2}$-coordination of the terahydroborate group. The geometry around the osmium atom can be rationalized as a distorted pentagonal bipyramid with the phosphine and the NHC ligands occupying axial positions $\left.(\mathrm{P}(1)-\mathrm{Os}-\mathrm{C}(1))=174.13(12)^{\circ}\right)$ The metal coordination sphere is completed with the hydride ligands and both boron bridging hydrogen atoms in the equatorial plane.

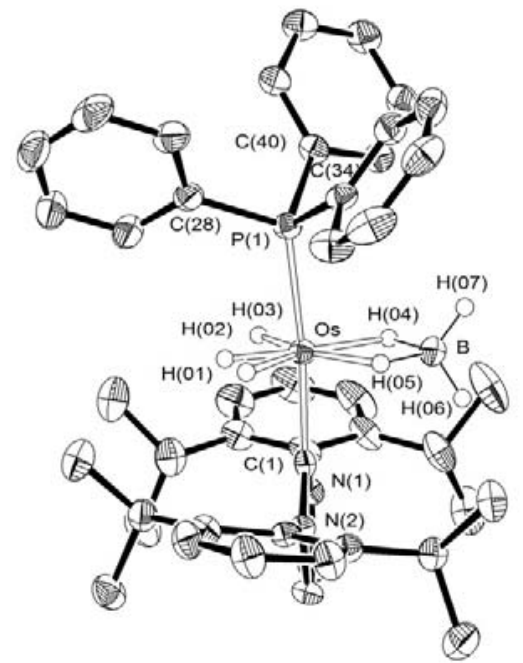

Figure 2. Molecular diagram of $\mathbf{8}$. Selected bond lengths $(\AA)$ and angles (deg): Os-B $=2.305(5)$, Os-H(04) $=1.71(5)$, B$\mathrm{H}(07)=1.01(3) ; \mathrm{P}(1)-\mathrm{Os}-\mathrm{C}(1)=174.13(12), \mathrm{H}(06)-\mathrm{B}-\mathrm{H}(07)=$ 114(4), H(05)-Os-H(01) = 96(2), H(04)-B-H(05) = 89(3), $\mathrm{H}(01)-O s-\mathrm{H}(02)=59(2), \mathrm{H}(02)-\mathrm{Os}-\mathrm{H}(03)=48(2)$. Displacement ellipsoids are given at the $50 \%$ probability level.

The bonding situation in the tetrahydrideborate complexes was analyzed by means of DFT calculations at the BP86/def2-SVP level, using the Atoms in Molecules (AIM) and Natural Bond Orbital (NBO) methods. Figure 3a shows the Laplacian distribution for $\mathbf{8}$ in the Os-H-B plane. This compound is characterized by the AIM method as a four-membered cyclic species possessing two Os-H and two B-H bond critical points associated with one OsHHB ring critical point. This particular topology, where the bond paths are inwardly curved, strongly resembles the situation found in $\mathrm{B}_{2} \mathrm{H}_{6}$ (Figure $3 \mathrm{~b}$ ). Thus, the computed electron densities $(\rho)$ and ellipticies $(\varepsilon)$ at the B-H bond critical points in $\mathbf{8}$ and diborane are consistent at the same level of theory: $\rho=0.16 \mathrm{e}^{-3}$ and $\varepsilon=0.08(\mathbf{8})$ versus $\rho=$ $0.17 \mathrm{e}^{-3}$ and $\varepsilon=0.04\left(\mathrm{~B}_{2} \mathrm{H}_{6}\right)$ for the terminal $\mathrm{B}-\mathrm{H}$ bonds, and $\rho=0.12 \mathrm{e} \AA^{-3}$ and $\varepsilon=0.04(8)$ versus $\rho=0.12 \mathrm{e}^{-3}$ and $\varepsilon=$ $0.03\left(\mathrm{~B}_{2} \mathrm{H}_{6}\right)$ for the bridging bonds. The computed NBOcharge at the boron atom of -0.35 e nicely agrees with its tetrahedral hybridization: $s p^{2.6}$ calculated at the terminal B-H bond and $s p^{3.6}$ calculated at the bridging B-H-Os bond. There is no Os-B ring critical point nor a bond path. This situation sharply contrasts with that found for bis- $\sigma$-borane $\mathbf{5}$, which is clearly characterized by the occurrence of an Os-B ring critical point by the AIM method. ${ }^{23}$ This difference is the result of a much stronger Os-B interaction in the latter as compared to $\mathbf{8}$, which is clearly reflected in the corresponding Wiberg bond indices, 1.02 for $\mathbf{5}$ versus 0.39 for $\mathbf{8}$.

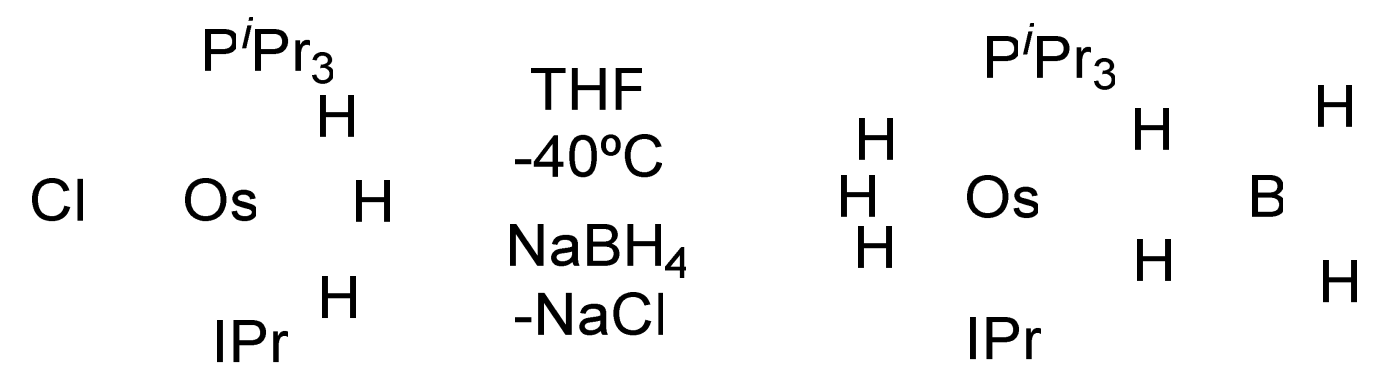



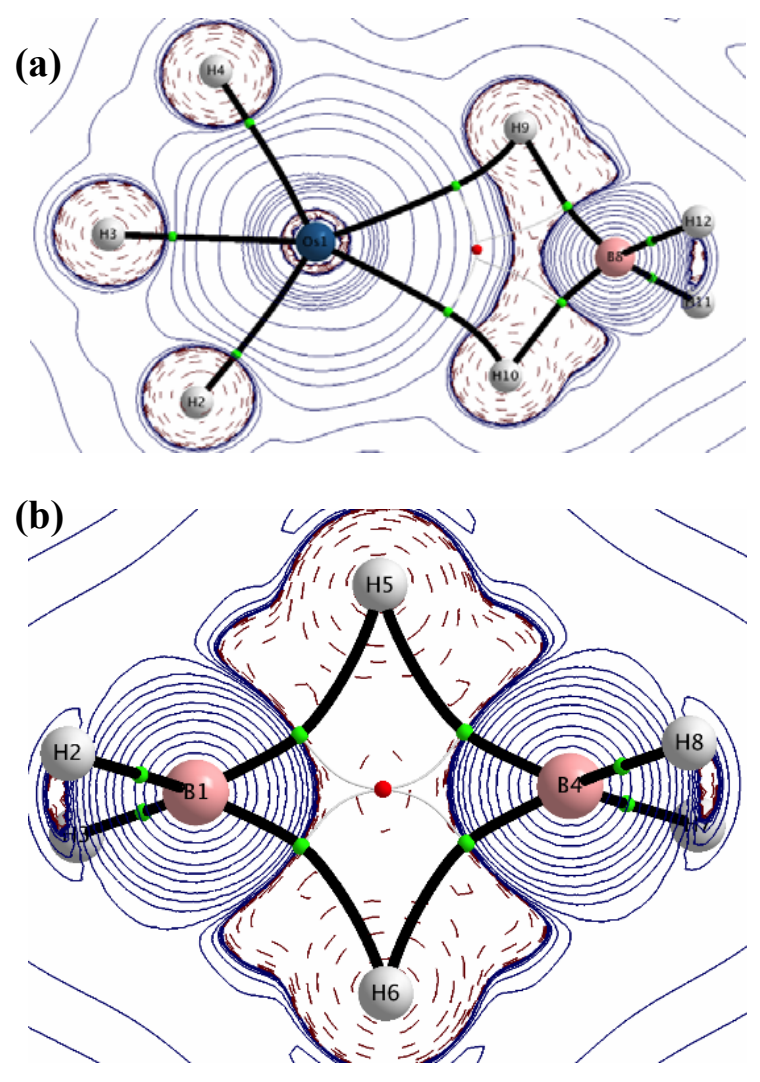

Figure 3. Contour line diagrams $\nabla^{2} \rho(\mathrm{r})$ for complex $\mathbf{O s H}_{3}\left(\kappa^{2}-\right.$ $\left.\mathbf{H}_{2} \mathbf{B H}_{2}\right)(\mathbf{I P r})\left(\mathbf{P P h}_{3}\right)$ in the Os-H-B plane (a) and for $\mathbf{B}_{2} \mathbf{H}_{6}$ in the B-H-B plane (b). The solid lines connecting the atomic nuclei are the bond paths while the small green and red spheres indicate the corresponding bond critical and ring critical points, respectively.

The ${ }^{1} \mathrm{H}$ NMR spectra of $\mathbf{7}$ and $\mathbf{8}$ in toluene- $d_{8}$ are temperature dependent. Figure 4 shows the ${ }^{1} \mathrm{H}\left\{{ }^{11} \mathrm{~B}\right\}$ NMR spectrum of 7 as a function of the temperature. At $233 \mathrm{~K}$, the spectra of both compounds show four signals for the $\mathrm{OsH}_{3}\left(\kappa^{2}-\mathrm{H}_{2} \mathrm{BH}_{2}\right)$ moiety, with a 1:1:2:3 intensity ratio, at 7.82 and $7.68\left(\mathrm{H}_{\mathrm{t}}\right.$ and $\left.\mathrm{H}_{\mathrm{t}}^{\prime}\right)$, $6.41(\mathrm{Hp})$ and $-12.74\left(\mathrm{H}_{\mathrm{a}}\right.$ and $\left.\mathrm{H}_{\mathrm{b}}\right)$ ppm for 7 and at $7.81\left(\mathrm{H}_{\mathrm{t}}\right.$ and $\left.\mathrm{H}_{\mathrm{t}}^{\prime}\right)$, -5.73 $\left(\mathrm{H}_{\mathrm{p}}\right)$, and $-11.53\left(\mathrm{H}_{\mathrm{a}}\right.$ and $\left.\mathrm{H}_{\mathrm{b}}\right)$ ppm for 8. The resonances due to the boron-bridging hydrogen atoms, $\mathrm{H}_{\mathrm{p}}$, and the hydride ligands, $\mathrm{H}_{\mathrm{a}}$ and $\mathrm{H}_{\mathrm{b}}$, coalesce at about $318 \mathrm{~K}$ for 7 and at about $333 \mathrm{~K}$ for 8 . This behavior is consistent with the existence of two intramolecular position exchange processes thermically activated (Scheme 2). The process of a lower energy barrier, involving the hydride ligands, is characteristic for $\mathrm{OsH}_{3} \mathrm{~L}_{2}\left(\mathrm{P}^{i} \mathrm{Pr}_{3}\right)_{2}$ species and seems to take place via dihydrogen intermediates, ${ }^{3}$ whereas that of higher activation energy corresponds to the position exchange between the hydride ligands and the boron-bridging hydrogen atoms, has an activation energy of about $14 \mathrm{kcal} \mathrm{mol}^{-1}$, and seems to occur very likely through seven-coordinate tetrahydride- $\sigma$-borane intermediates. ${ }^{31 b, 33}$ In contrast to the ${ }^{1} \mathrm{H}$ NMR spectra, the ${ }^{13} \mathrm{C}\left\{{ }^{1} \mathrm{H}\right\}$, ${ }^{31} \mathrm{P}\left\{{ }^{1} \mathrm{H}\right\}$ and ${ }^{11} \mathrm{~B}\left\{{ }^{1} \mathrm{H}\right\}$ NMR spectra are temperature invariant between $193 \mathrm{~K}$ and $338 \mathrm{~K}$. In the ${ }^{13} \mathrm{C}\left\{{ }^{1} \mathrm{H}\right\}$ NMR spectra, the most noticeable feature is the resonance due to the metalated carbene carbon atom, which appears at $184.6 \mathrm{ppm}$ for 7 and at 182.5 for $\mathbf{8}$ as a doublet with a C-P coupling constant of 87.0 $\mathrm{Hz}$ for 7 and of $91.5 \mathrm{~Hz}$ for $\mathbf{8}$. The ${ }^{31} \mathrm{P}\left\{{ }^{1} \mathrm{H}\right\}$ NMR spectra show a singlet at $40.9 \mathrm{ppm}$ for 7 and at $24.7 \mathrm{ppm}$ for $\mathbf{8}$, whereas the ${ }^{11} \mathrm{~B}\left\{{ }^{1} \mathrm{H}\right\}$ spectra contain a broad signal at 17.8 ppm for 7 and at 19.4 ppm for 8 .

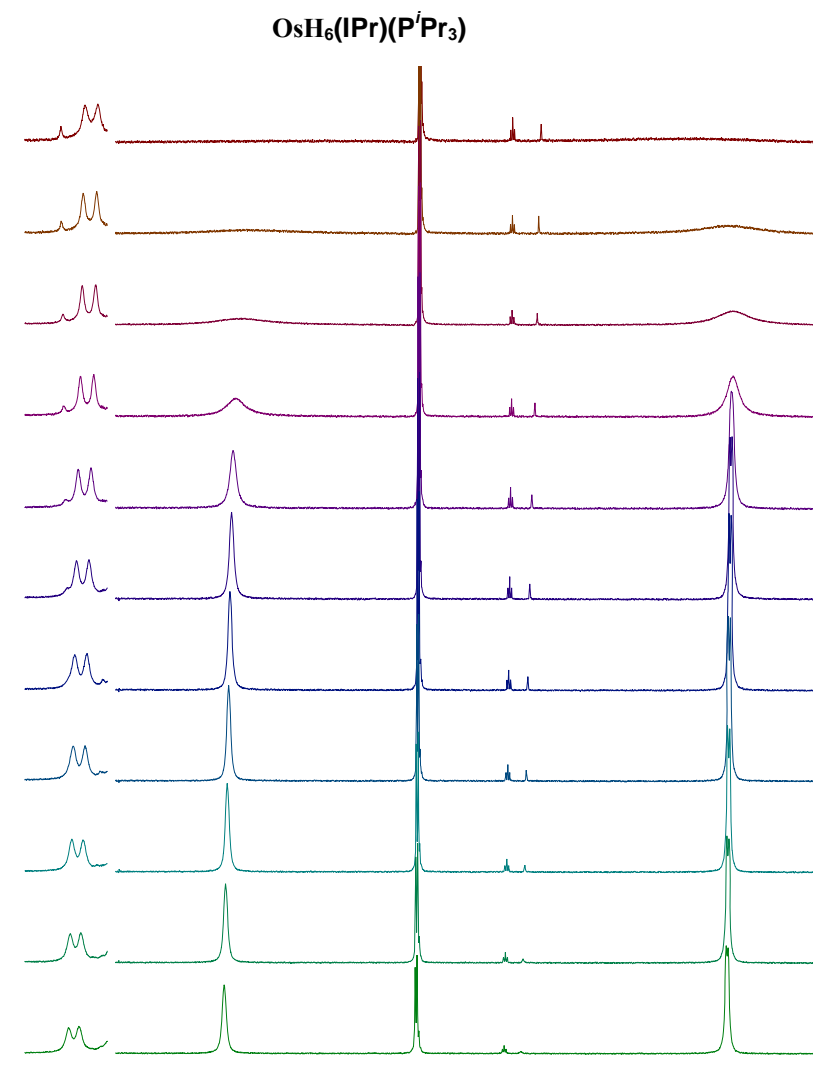

Figure 4 Low- $(\delta, 8.4-7.4)$ and high-field region of the ${ }^{1} \mathrm{H}\left\{{ }^{11} \mathrm{~B}\right\}$ NMR spectrum of 7 as a function of temperature.

Scheme 2

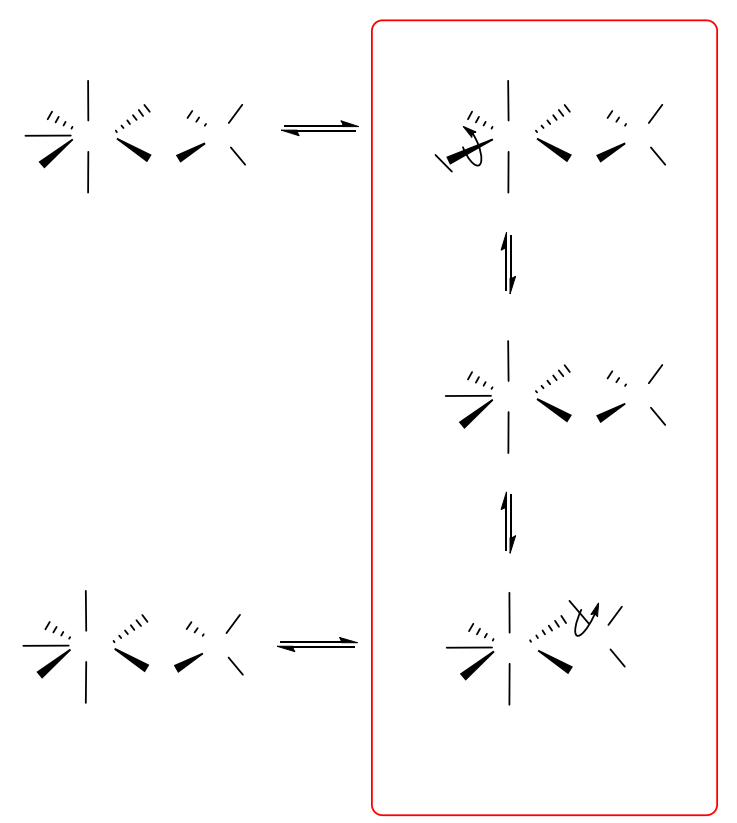

Nucleophiles abstract $\mathrm{BH}_{3}$ from a coordinated tetrahydrideborate group, in particular when the rupture of an M-H-B bridge takes place. ${ }^{34}$ In agreement with this, complexes $\mathbf{7}$ and $\mathbf{8}$ are unstable in 2-propanol. Because the $\mathrm{OsH}_{4}(\mathrm{IPr})\left(\mathrm{PR}_{3}\right)$ species 
resulting from the extraction dehydrogenate alcohols, at room temperature, the stirring of 2-propanol solutions of these compounds for $4 \mathrm{~h}$ gives rise to the quantitative formation of the hexahydride derivatives $\mathrm{OsH}_{6}(\mathrm{IPr})\left(\mathrm{PR}_{3}\right)\left(\mathrm{PR}_{3}=\mathrm{P}^{i} \mathrm{Pr}_{3}\left(\right.\right.$ 9), $\mathrm{PPh}_{3}$ (10)). These compounds were isolated as white solids (eq 4). In accordance with the presence of six-hydride ligands in the complexes, their ${ }^{1} \mathrm{H}$ NMR spectra, in benzene- $d_{6}$, at room temperature show a $\operatorname{doublet}\left({ }^{2} J_{\mathrm{H}-\mathrm{P}} \approx 10 \mathrm{~Hz}\right)$, at $-8.81 \mathrm{ppm}$ for 9 and at $\mathbf{-} 7.37 \mathrm{ppm}$ for $\mathbf{1 0}$, which displays an integration intensity of 6.The ${ }^{31} \mathrm{P}\left\{{ }^{1} \mathrm{H}\right\}$ NMR spectra contain a singlet, at 56.5 ppm for $\mathbf{9}$ and at $25.5 \mathrm{ppm}$ for $\mathbf{1 0}$, which is split into a septet under off-resonance conditions. In the ${ }^{13} \mathrm{C}\left\{{ }^{1} \mathrm{H}\right\}$ NMR spectra, the metalated carbene carbon atom displays a doublet at 177.5 ppm for $\mathbf{9}$ and at 176.5 ppm for $\mathbf{1 0}$ with a C-P coupling constants of $56.6 \mathrm{~Hz}$ and $63.5 \mathrm{~Hz}$, respectively.

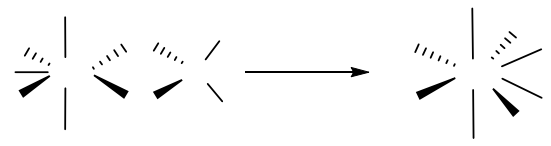

A few $\mathrm{d}^{2}$-hexahydride derivatives are known for osmium in the iron triade. Although recently an example containing the disphosphine 9,9-dimethyl-4,5bis(diisopropylphosphine)xanthane $\left(\operatorname{xant}\left(\mathrm{P}^{\mathrm{i}} \mathrm{Pr}_{2}\right)_{2}\right)$ has been reported, ${ }^{35}$ they are generally stabilized with two monodentated phosphine co-ligands. ${ }^{32,36}$ In contrast to ruthenium, the $\mathrm{OsH}_{6}$-species are classical polyhydrides. This fact has been confirmed by means of the neutron diffraction structure of $\mathrm{OsH}_{6}\left(\mathrm{P}^{i} \mathrm{Pr}_{2} \mathrm{Ph}\right)_{2}$. The geometry of the inner coordination sphere can be described as a dodecahedron defined by two orthogonal BAAB trapezoidal planes, with the heavy atoms at the B sites of one of them. ${ }^{37}$ Complex 9 and $\mathbf{1 0}$ are the first mixed $\mathrm{R}_{3} \mathrm{P}-$ M-NHC members of this family of compounds.

3. Reduction and $\mathbf{C}-\mathbf{H}$ bond activation of benzonitrile. The hexahydride complexes $\mathbf{9}$ and $\mathbf{1 0}$ propathe reduction of the $\mathrm{C} \equiv \mathrm{N}$ triple bond of benzonitrile and the subsequent chelateas sisted ortho-CH bond actiyation of the resultin - mine. Thus, the treatment of toluene solutions of these compounds with 1.1 equiv of the nitrile, under froflux, fo $\bigcirc$ Sleads to the trihy derivatives $\left.\mathrm{OsH}_{3}\left\{\kappa^{2}-\mathrm{N}, \mathrm{C}-\mathrm{N} \mathrm{N}=\mathrm{H}=\mathrm{CH}-\mathrm{C}_{6} \mathrm{H}_{4}\right)\right\}(\mathrm{IPr})\left(\mathrm{PR}_{3}\right)\left(\mathrm{PR}_{3}=\right.$ $\mathrm{P}^{i} \mathrm{Pr}_{3}$ (11), $\mathrm{PPh}_{3}(\mathbf{1 2})$ ), containing an stabilized $\mathrm{fr}$ o-metalated phenylmethanimine. Complexes 11 and 12 were isolated as orange solids in about $75 \%$ yield (ed B).r

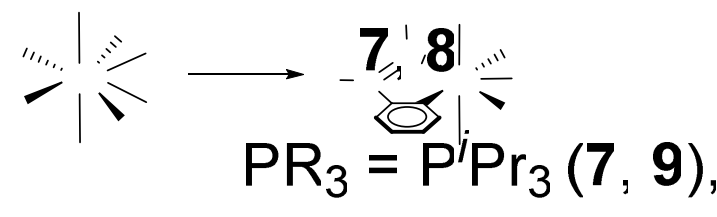

Complex 11 was characterized by X-ray diffraction analysis. Figure 5 shows a view of the structure, which proves the stabilization of the aldimine. The complex presents a pentagonalbipyramidal geometry with the phosphine and the NHC ligands in axial positions $\left(\mathrm{P}(1)\right.$-Os- $\left.\mathrm{C}(8)=166.68(9)^{\circ}\right)$, whereas the three hydride ligands and the chelated group $\left(\mathrm{N}(1)-O s-\mathrm{C}(8)=74.13(12)^{\circ}\right)$ lie in the equatorial plane. The five-membered ring formed by the ortho-metalated imine and the osmium atom is almost planar. The Os- $\mathrm{N}(1)$ bond length of 2.118(3) and the Os-C(1) distance of 2.126(3) are typical for Os-N and Os- $\mathrm{C}_{\text {aryl }}$ single bonds and are in agreement with those previously reported for other osmium complexes containing ortho-metalated imines. ${ }^{38}$

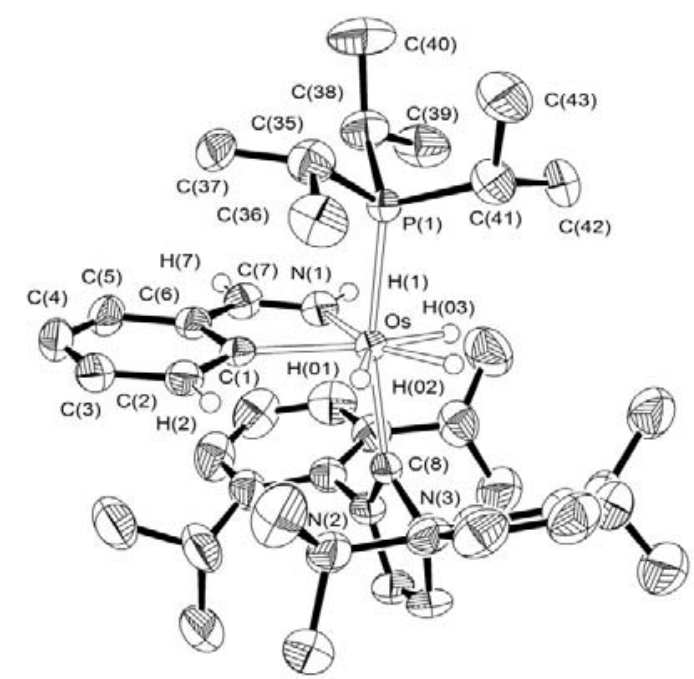

Figure 5. Molecular diagram of 11. Selected bond lengths $(\AA)$ and angles (deg): Os-N(1) = 2.118(3), Os-C(1) = 2.126(3); $\mathrm{P}(1)$-Os- $\mathrm{C}(8)=166.68(9)^{\circ}, \mathrm{N}(1)-\mathrm{Os}-\mathrm{C}(8)=74.13(12)^{\circ}$,

The ${ }^{1} \mathrm{H},{ }^{13} \mathrm{C}\left\{{ }^{1} \mathrm{H}\right\}$ and ${ }^{31} \mathrm{P}\left\{{ }^{1} \mathrm{H}\right\}$ NMR spectra of $\mathbf{1 1}$ and 12, in toluene- $d_{8}$, are consistent with the structure shown in Figure 5. In agreement with the presence of three inequivalent hydrides ligand in these compounds, the ${ }^{1} \mathrm{H}$ NMR spectra in the high field region, at $223 \mathrm{~K}$, show three resonances at $-6.68,-9.37$, and $-9.61 \mathrm{ppm}$ for $\mathbf{1 1}$ and at $-5.79,-8.72$, and at $-8.96 \mathrm{ppm}$ for 12. In the low field region of the spectra, the most noticeable feature is the $\mathrm{NH}$ signal, which appears at $9.33 \mathrm{ppm}$ for $\mathbf{1 1}$ and at $8.76 \mathrm{ppm}$ for $\mathbf{1 2}$. In the ${ }^{13} \mathrm{C}\left\{{ }^{1} \mathrm{H}\right\}$ NMR spectra, the resonance corresponding to the metalated phenyl carbon atom appears at $191.8 \mathrm{ppm}$ for $\mathbf{1 1}$ an $\$ 7 \mathrm{ppm}$ for $\mathbf{1 2}$ as a doublet with a C-P coupling constant of $\mathbf{X} . \mathbf{B z}$ for $\mathbf{1 1}$ and of $9.2 \mathrm{~Hz}$ for 12, whereas the signal due to the metlated carbene carbon

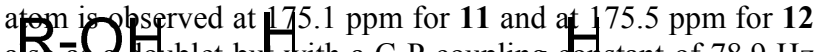
asd a doublet but with a C-P coupling donstant of $78.9 \mathrm{~Hz}$ for 11 and of $94.8 \mathrm{~Hz}$ for 12. $\mathrm{D} \mathbf{S}^{31} \mathrm{P}\left\{{ }^{1} \mathrm{H}\right\}$ NMR spedtucpntain a singlet at $19.7 \mathrm{ppm}$ for $\mathbf{1 1}$ and at $21.8 \mathrm{pmm}$ for $\mathbf{1 2}$.

\section{Concluding Remarks}

This study has revealed that the borylation of the metal-carbon

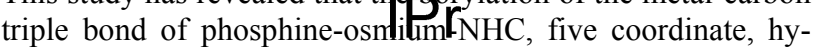
dride-alkylidyne complexes with the tetrahydrideborate anion under alcoholysis conditions the to access polyhydrides stabilized by phosphine-osmium-NHC skeletons. Thus, the first compounds of four different types of mixed polyhydrides

\section{$\mathrm{Pl}_{3}$ (8epofld) $\quad \mathrm{OsH}_{3} \mathrm{Cl}(\mathrm{NHC})\left(\mathrm{PR}_{3}\right), \quad \mathrm{OsH}_{3}\left(\kappa^{2}-\right.$

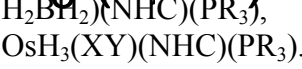 $\mathrm{OsH}_{6}(\mathrm{NHC})\left(\mathrm{PR}_{3}\right), \quad$ and}

Arrangements to form the homoleptic species have not been observed in any case, despite relatively drastic experimental conditions, such as 2-propanol or toluene under reflux, have been used in some occasions. The mutually trans disposition of the heavy co-ligands and the small size of the hydrides, which prevent ligand dissotiation process, disfavor the ligand exchange from a kinetic point of view. Furthermore, the complementary properties of phosphines and NHC ligands, mainly 
$\sigma$-donor the first ones and quite $\pi$-acceptor the latter, ${ }^{12 \mathrm{e}}$ stabilize the skeleton of the polyhydride.

Because the previous developed procedure to prepare the fivecoordinate hydride-alkylidene starting compounds is compatible with a wide range of phosphines and NHC ligands, this entry should allow the preparation of polyhydrides with a wide range of skeletons of this type. Furthermore, as the nature of the interactions between the hydrogen atoms coordinated to the metal center and those of the latter with the hydrogens depend upon the electronic properties of the heavy co-ligands, a very fine turning of the characteristic of the hydrides should be achieved by combining different phosphine and NHC groups at the skeleton. So, the use of these skeletons should allow a better control of the polyhydride properties.

In conclusion, an entry to the first families of stable mixed phophine-osmium-NHC polyhydrides is described. Given the potential of the osmium polyhydrides and the subtle govern of the electron density of the metal center of the polyhydride that can be performed through the combination of ligands, a promising chemistry should be expected for this type of compounds.

\section{EXPERIMENTAL SECTION}

All reactions were carried out with rigorous exclusion of air using Shlenck-tube techniques. Solvents were dried by standard procedures and distilled under argon prior to use. The starting materials $\left[\mathrm{OsHCl}(\equiv \mathrm{CPh})(\mathrm{IPr})\left(\mathrm{PR}_{3}\right)\right] \mathrm{OTf}\left(\mathrm{PR}_{3}=\mathrm{P}^{i} \mathrm{Pr}_{3},(\mathbf{1}), \mathrm{PPh}_{3}(\mathbf{2})\right)$ were prepared by the published method. ${ }^{91} \mathrm{H},{ }^{13} \mathrm{C}\left\{{ }^{1} \mathrm{H}\right\},{ }^{31} \mathrm{P}\left\{{ }^{1} \mathrm{H}\right\}$ and ${ }^{11} \mathrm{~B}\left\{{ }^{1} \mathrm{H}\right\}$ NMR Spectra were recorded on a Bruker Avance $300 \mathrm{MHz}$ or a Bruker Avance $400 \mathrm{MHz}$ instrument. Chemical shifts (expressed in parts per million) are referenced to residual solvent peaks $\left({ }^{1} \mathrm{H}\right.$, $\left.{ }^{13} \mathrm{C}\left\{{ }^{1} \mathrm{H}\right\}\right)$ or external $\mathrm{H}_{3} \mathrm{PO}_{4}\left({ }^{31} \mathrm{P}\left\{{ }^{1} \mathrm{H}\right\}\right)$ and $\mathrm{BF}_{3} \cdot \mathrm{EtO}_{2}\left({ }^{11} \mathrm{~B}\left\{{ }^{1} \mathrm{H}\right\}\right)$. Coupling constants $J$ are given in hertz. Attenuated total reflection infrared spectra (ATR-IR) of solid samples were run on a Perkin-Elmer Spectrum 100 FT-IR spectrometer. C, H, and O Analyses were carried out with a Perkin-Elmer $2400 \mathrm{CHNS} / \mathrm{O}$ analyzer. High-resolution electrospray mass spectra were acquired using a MicroTOF-Q hybrid quadrupole time-of-fly spectrometer (Bruker Daltonics, Bremen, Germany).

\section{Computational details.}

Geometry optimizations without symmetry constraints for compounds 8 and $\mathrm{B}_{2} \mathrm{H}_{6}$ were carried out with the Gaussian $09^{39}$ suite of programs using the $\mathrm{BP} 86^{40}$ functional in combination with the def2$\mathrm{SVP}^{41}$ basis set for all atoms. The osmium atom was calculated with a quasi-relativistic effective core potential. ${ }^{42}$ The BP86/def2-SVP level was selected because it was previously used to study the bonding situation of related complexes having Os-B interactions. ${ }^{22-23,28}$ Stationary points were characterized by calculating the Hessian matrix analytically to confirm that all species are minima on the potential energy surface.

Wiberg Bond Indices (WBI) were computed using the Natural Bond Orbital (NBO) method. ${ }^{43}$ All AIM results described in this work correspond to calculations performed at the BP86/6$31+\mathrm{G}(\mathrm{d}) / \mathrm{WTBS}$ (for Os) level on the optimized geometries obtained at the BP86/def2-SVP level. The WTBS (well-tempered basis sets) ${ }^{44}$ have been recommended for AIM calculations involving transition metals. ${ }^{45}$ The topology of the electron density was conducted using the AIMAll program package. ${ }^{46}$

Preparation of $\mathrm{OsH}_{3} \mathrm{Cl}(\mathrm{IPr})\left(\mathrm{P}^{i} \mathbf{P r}_{3}\right)$ (6). A yellow solution of $\mathrm{OsH}_{2} \mathrm{Cl}\left(\eta^{2}-\mathrm{H}-\mathrm{BCH}_{2} \mathrm{Ph}\right)(\mathrm{IPr})\left(\mathrm{P}^{i} \mathrm{Pr}_{3}\right)(3)(100 \mathrm{mg}, 0.114 \mathrm{mmol})$ in 10 $\mathrm{mL}$ of 2-propanol was stirred for $4 \mathrm{~h}$ at $110^{\circ} \mathrm{C}$. The resulting red solution was evaporated to dryness to afford a red solid. Yield $84 \mathrm{mg}$ (95\%). ${ }^{1} \mathrm{H}$ NMR (300 MHz, $\left.\mathrm{C}_{6} \mathrm{D}_{6}, 298 \mathrm{~K}\right): \delta 7.30-7.19(6 \mathrm{H}, \mathrm{Ph}), 6.63$ (s, 2H, NCH), $3.3\left(\mathrm{hpt},{ }^{3} J_{\mathrm{H}-\mathrm{H}}=6.8,4 \mathrm{H}, \mathrm{CHCH}_{3}\right), 1.94(\mathrm{~m}, 3 \mathrm{H}, \mathrm{PCH})$, 1.54, 1.11 (both d, $\left.{ }^{3} J_{\mathrm{H}-\mathrm{H}}=6.8,12 \mathrm{H}, \mathrm{CHCH}_{3}\right), 0.90\left(\mathrm{dd},{ }^{3} J_{\mathrm{H}-\mathrm{H}}=12.6\right.$, ${ }^{3} J_{\mathrm{H}-\mathrm{P}}=7.1,18 \mathrm{H}, \mathrm{PCHCH}{ }_{3}$ ), -19.53 (s wide, $3 \mathrm{H}, \mathrm{OsH}$ ). ${ }^{1} \mathrm{H}\left\{{ }^{31} \mathrm{P}\right\} \mathrm{NMR}$ $\left(300 \mathrm{MHz}, \mathrm{C}_{6} \mathrm{D}_{6}, 183 \mathrm{~K}\right): \delta_{\mathrm{A}}=-15.16, \delta_{\mathrm{B}}=-21.17\left(\mathrm{AB}_{2}\right.$ pattern, $J_{\mathrm{AB}}=$ 290,OsH 3 ). ${ }^{31} \mathrm{P}\left\{{ }^{1} \mathrm{H}\right\}$ NMR (121.4 MHz, $\left.\mathrm{C}_{6} \mathrm{D}_{6}, 298 \mathrm{~K}\right): \delta 47.7$ (s). ${ }^{13} \mathrm{C}\left\{{ }^{1} \mathrm{H}\right\}$-APT NMR $\left(75.4 \mathrm{MHz}, \mathrm{C}_{6} \mathrm{D}_{6}, 298 \mathrm{~K}\right): \delta 170.0\left(\mathrm{~d},{ }^{2} J_{\mathrm{C}-\mathrm{P}}=74\right.$, OsC) $147.0,136.9,126.9,123.6$ (all s, Ph), 122.6 (s, NCH), 28.9 (s, $\left.\mathrm{CHCH}_{3}\right) 26.6\left(\mathrm{~d},{ }^{1} J_{\mathrm{C}-\mathrm{P}}=22.4, \mathrm{PCH}\right), 25.9,22.6$ (both s, $\left.\mathrm{CHCH}_{3}\right), 20.3$ (s, $\mathrm{PCHCH}_{3}$ ).

Preparation of $\mathrm{OsH}_{3}\left(\eta^{2}-\mathbf{H}_{2} \mathbf{B H}_{2}\right)(\operatorname{IPr})\left(\mathbf{P}^{i} \mathbf{P r}_{3}\right)$ (7). Method A: A red solution of $\mathrm{OsH}_{3} \mathrm{Cl}(\mathrm{IPr})\left(\mathrm{P}^{i} \mathrm{Pr}_{3}\right)(6)(88.4 \mathrm{mg}, 0.114 \mathrm{mmol})$ in $5 \mathrm{~mL}$ of THF was treated with $\mathrm{Na}\left[\mathrm{BH}_{4}\right](6.5 \mathrm{mg}, 0.171 \mathrm{mmol})$. The mixture was stirred for 15 minutes at $-40{ }^{\circ} \mathrm{C}$, and the resulting dark red solution was evaporated to dryness. The residue was treated with $10 \mathrm{~mL}$ of toluene and the mixture was filtered through Celite. The solution was then evaporated to dryness. The residue was washed with cold pentane $(2 \times 1 \mathrm{~mL})$ to afford a yellow solid which was dried in vacuo. Yield: $37.5 \mathrm{mg}(44 \%)$. Method B: An orange solution of $\left[\mathrm{OsHCl}(\equiv \mathrm{CPh})(\mathrm{IPr})\left(\mathrm{P}^{i} \mathrm{Pr}_{3}\right)\right] \mathrm{OTf}(\mathbf{2})(200 \mathrm{mg}, 0.197 \mathrm{mmol})$ in $9.5 \mathrm{~mL}$ of THF was treated with $\mathrm{Na}\left[\mathrm{BH}_{4}\right](111.7 \mathrm{mg}, 2.96 \mathrm{mmol})$ in the presence of $0.5 \mathrm{~mL}$ of methanol. The mixture was stirred for 10 minutes at $-60{ }^{\circ} \mathrm{C}$. The resulting dark red solution was evaporated to dryness. The residue was treated with $10 \mathrm{~mL}$ of toluene and the suspension was filtered through Celite. The solution was then evaporated to dryness. The residue was washed with cold pentane $(2 \times 1 \mathrm{~mL})$ to give a yellow solid which was dried in vacuo. Yield: $55.3 \mathrm{mg}(37 \%)$. Anal. Calcd for $\mathrm{C}_{36} \mathrm{H}_{64} \mathrm{~N}_{2} \mathrm{OsP}$ : C, 57.12; H, 8.52; N, 3.70. Found. C, $56.80 ; \mathrm{H}, 8.21 ; \mathrm{N}, 3.39$. IR $\left(\mathrm{cm}^{-1}\right): v(\mathrm{BH}) 2418$ and $2437 ; \mathrm{v}(\mathrm{OsH})$ 2098 and $2152 \mathrm{~cm}^{-1}$. ${ }^{1} \mathrm{H}$ NMR (300 MHz, $\left.\mathrm{C}_{6} \mathrm{D}_{6}, 298 \mathrm{~K}\right): \delta 7.75(\mathrm{~s}$ wide, $\left.2 \mathrm{H}, \mathrm{BH}_{\mathrm{t}}+\mathrm{BH}_{\mathrm{t}}{ }^{\prime}\right), 7.30-7.20(6 \mathrm{H}, \mathrm{Ph}), 6.67(\mathrm{~s}, 2 \mathrm{H}, \mathrm{NCH}), 3.13$ $\left(\mathrm{hpt},{ }^{3} J_{\mathrm{H}-\mathrm{H}}=6.8,4 \mathrm{H}, \mathrm{CHCH}_{3}\right), 1.73(\mathrm{~m}, 3 \mathrm{H}, \mathrm{PCH}), 1.48,1.10$ (both d, $\left.{ }^{3} J_{\mathrm{H}-\mathrm{H}}=6.8,24 \mathrm{H}, \mathrm{CHCH}_{3}\right), 0.91\left(\mathrm{dd},{ }^{3} J_{\mathrm{H}-\mathrm{H}}=12.4,{ }^{3} J_{\mathrm{H}-\mathrm{P}}=7.1,18 \mathrm{H}\right.$, $\mathrm{PCHCH}_{3}$ ), -6.43 (s wide, $2 \mathrm{H}, \mathrm{BH}_{\mathrm{p}} \mathrm{Os}$ ), -12.75 (s wide, $3 \mathrm{H}, \mathrm{OsH}_{\mathrm{a}}+$ $\left.\mathrm{OsH}_{\mathrm{b}}\right) .{ }^{1} \mathrm{H}$ NMR $\left(400 \mathrm{MHz}, \mathrm{C}_{7} \mathrm{D}_{8}, 233 \mathrm{~K}\right): \delta 7.82\left(\mathrm{~s}, 1 \mathrm{H}, \mathrm{BH}_{\mathrm{t}}\right), \delta 7.68$ (s, 1H, BH' ), -6.41 (s wide, $2 \mathrm{H}, \mathrm{BH}_{\mathrm{p}} \mathrm{Os}$ ), -12.74 (s wide, $3 \mathrm{H}, \mathrm{OsH}_{\mathrm{a}}+$ $\left.\mathrm{OsH}_{\mathrm{b}}\right) .{ }^{31} \mathrm{P}\left\{{ }^{1} \mathrm{H}\right\}$ NMR $\left(121.4 \mathrm{MHz}, \mathrm{C}_{6} \mathrm{D}_{6}, 298 \mathrm{~K}\right): \delta 40.9(\mathrm{~s}) .{ }^{11} \mathrm{~B}$ NMR (96.2MHz, $\left.\mathrm{C}_{6} \mathrm{D}_{6}, 298 \mathrm{~K}\right): \delta 17.8 .{ }^{13} \mathrm{C}\left\{{ }^{1} \mathrm{H}\right\}$-APT NMR (75.4 $\left.\mathrm{MHz}, \mathrm{C}_{6} \mathrm{D}_{6}, 298 \mathrm{~K}\right): \delta 184.6\left(\mathrm{~d},{ }^{2} J_{\mathrm{C}-\mathrm{P}}=87.0\right.$, OsC), 146.8, 139.0, 129.7, 124.0 (all s, Ph), $122.6(\mathrm{~s}, \mathrm{NCH}), 29.1\left(\mathrm{~s}, \mathrm{CHCH}_{3}\right), 26.7$ (d, ${ }^{1} J_{\mathrm{C}-}$ $\left.\mathrm{p}=22.8, \mathrm{PCHCH}_{3}\right), 26.1\left(\mathrm{~s}, \mathrm{CHCH}_{3}\right), 22.5\left(\mathrm{~s}, \mathrm{PCHCH}_{3}\right), 20.6(\mathrm{~s}$, $\mathrm{CHCH}_{3}$ ).

Preparation of $\mathrm{OsH}_{3}\left(\eta^{2}-\mathrm{H}_{2} \mathrm{BH}_{2}\right)(\mathrm{IPr})\left(\mathrm{PPh}_{3}\right)(8)$. An orange solution of $\left[\mathrm{OsHCl}(\equiv \mathrm{CPh})(\mathrm{IPr})\left(\mathrm{PPh}_{3}\right)\right] \mathrm{OTf}(\mathbf{2})(150 \mathrm{mg}, 0.134 \mathrm{mmol})$ in $9.5 \mathrm{~mL}$ of THF was treated with $\mathrm{Na}\left[\mathrm{BH}_{4}\right](75.98 \mathrm{mg}, 2.01 \mathrm{mmol})$ in the presence of $0.5 \mathrm{~mL}$ of methanol. The mixture was stirred for 10 minutes at $-60{ }^{\circ} \mathrm{C}$. The resulting dark red solution was evaporated to dryness. The residue was treated with $10 \mathrm{~mL}$ of toluene and the suspension was filtered through Celite. The solution was then evaporated to dryness. The residue was washed with cold pentane $(4 \times 2 \mathrm{~mL})$ to give a yellow solid which was dried in vacuo. Yield: $34.4 \mathrm{mg}(30 \%)$. Anal. Calcd for $\mathrm{C}_{45} \mathrm{H}_{58} \mathrm{BN}_{2} \mathrm{OsP}$ : C, 62.92; H, 6.81; N, 3.26. Found: C, 62.71; H, 6.47; N, 3.02. HRMS (electrospray, m/z): $\mathrm{C}_{45} \mathrm{H}_{51} \mathrm{BN}_{2} \mathrm{OsP}$ [M - 7H]: 853.3502, found: 853.3569. IR (Nujol, $\left.\mathrm{cm}^{-1}\right): v(\mathrm{BH}) 2435$ and 2332; v(OsH) 2120 and $2024 \mathrm{~cm}^{-1}$. ${ }^{1} \mathrm{H}$ NMR $\left(300 \mathrm{MHz}, \mathrm{C}_{6} \mathrm{D}_{6}\right.$, 298K): $\delta 7.50-7.41(5 \mathrm{H}, \mathrm{PPh}), 7.27,7.24,7.13\left(\right.$ all d, ${ }^{3} J_{\mathrm{H}-\mathrm{H}}=7.7,6 \mathrm{H}$, $\mathrm{Ph}), 7.00-6.90(10 \mathrm{H}, \mathrm{PPh}), 6.64(\mathrm{~s}, 2 \mathrm{H}, \mathrm{NCH}), 3.11\left(\mathrm{hpt},{ }^{3} J_{\mathrm{H}-\mathrm{H}}=6.8\right.$, $4 \mathrm{H}, \mathrm{CHCH}_{3}$ ), 1.37, 1.07 (both d, $\left.{ }^{3} J_{\mathrm{H}-\mathrm{H}}=6.8,24 \mathrm{H}, \mathrm{CHCH}_{3}\right),-5.73(\mathrm{~s}$ wide, $2 \mathrm{H}, \mathrm{BH}_{\mathrm{p}} \mathrm{Os}$ ), -11.53 (s wide, $3 \mathrm{H}, \mathrm{OsH}_{\mathrm{a}}+\mathrm{OsH}_{\mathrm{b}}$ ). ${ }^{1} \mathrm{H}$ NMR (400 $\mathrm{MHz}, \mathrm{C}_{7} \mathrm{D}_{8}, 243 \mathrm{~K}$ ): $\delta 7.81$ (wide, $2 \mathrm{H}, \mathrm{BH}_{\mathrm{t}}+\mathrm{BH}_{\mathrm{t}}$ ), -5.73 (s wide, $2 \mathrm{H}$, $\left.\mathrm{BH}_{\mathrm{p}} \mathrm{Os}\right),-11.53\left(\mathrm{~d},{ }^{2} J_{\mathrm{H}-\mathrm{P}}=12.0 \mathrm{~Hz}, 3 \mathrm{H}, \mathrm{OsH}_{\mathrm{a}}+\mathrm{OsH}_{\mathrm{b}}\right) .{ }^{31} \mathrm{P}\left\{{ }^{1} \mathrm{H}\right\} \mathrm{NMR}$ $\left(121.4 \mathrm{MHz}, \mathrm{C}_{6} \mathrm{D}_{6}, 298 \mathrm{~K}\right): \delta 24.7$ (s). ${ }^{11} \mathrm{~B} \mathrm{NMR}\left(96.2 \mathrm{MHz}, \mathrm{C}_{6} \mathrm{D}_{6}\right.$, $298 \mathrm{~K}): \delta 19.4 .{ }^{13} \mathrm{C}\left\{{ }^{1} \mathrm{H}\right\}$-APT NMR, HSQC and HMBC $(75.4 \mathrm{MHz}$, $\left.\mathrm{C}_{6} \mathrm{D}_{6}, 298 \mathrm{~K}\right): \delta 182.5\left(\mathrm{~d},{ }^{2} J_{\mathrm{C}-\mathrm{P}}=91.5\right.$, OsC), $146.6(\mathrm{~s}, \mathrm{Ph}), 140.8(\mathrm{~d}$, $\left.{ }^{1} J_{\mathrm{C}-\mathrm{P}}=42.9, \mathrm{C}_{i p s o}-\mathrm{PPh}\right), 138.7(\mathrm{~s}, \mathrm{Ph}), 134.6\left(\mathrm{~d}, J_{\mathrm{C}-\mathrm{P}}=11.3, \mathrm{PPh}\right), 129.9$ $(\mathrm{s}, \mathrm{Ph}), 128.8\left(\mathrm{~d}, J_{\mathrm{C}-\mathrm{P}}=1.9, \mathrm{PPh}\right), 127.5\left(\mathrm{~d}, J_{\mathrm{C}-\mathrm{P}}=9.2, \mathrm{PPh}\right), 124.2(\mathrm{~s}$, $\mathrm{Ph}$ ), 122.8 (s, NCH), $29.2\left(\mathrm{~s}, \mathrm{CHCH}_{3}\right.$ ), 26.1, 22.4 (both s, $\mathrm{CHCH}_{3}$ ).

Preparation of $\mathrm{OsH}_{6}(\mathbf{I P r})\left(\mathbf{P}^{i} \mathbf{P r}_{3}\right)$ (9). A yellow solution of $\mathrm{OsH}_{3}\left(\eta^{2}-\mathrm{H}_{2} \mathrm{BH}_{2}\right)(\mathrm{IPr})\left(\mathrm{P}^{i} \mathrm{Pr}_{3}\right)(7)(100 \mathrm{mg}, 0.132 \mathrm{mmol})$ in $5 \mathrm{~mL}$ of 2 propanol was stirred for $4 \mathrm{~h}$ at room temperature, and the resulting red solution was evaporated to dryness. The residue was washed with cold pentane $(2 \times 1 \mathrm{~mL})$ obtaining a white solid which was dried in vacuo. Yield: $43.58 \mathrm{mg}(44 \%)$. Anal. Calcd for $\mathrm{C}_{36} \mathrm{H}_{64} \mathrm{~N}_{2} \mathrm{OsP}$ : C, 58.03; H, 8.52; N, 3.76. Found: C, 57.68; H, 8.24; N, 3.61. HRMS (electrospray, m/z): $\mathrm{C}_{38} \mathrm{H}_{63} \mathrm{~N}_{3} \mathrm{OsP}\left[\mathrm{M}-4 \mathrm{H}+\mathrm{CH}_{3} \mathrm{CN}\right]$ : 784.4362 . 
Found: 784.4371. IR $\left(\mathrm{cm}^{-1}\right): v(\mathrm{OsH}) 1882$ and $1972 \mathrm{~cm}^{-1} .{ }^{1} \mathrm{H}$ NMR (400 MHz, $\left.\mathrm{C}_{6} \mathrm{D}_{6}, 298 \mathrm{~K}\right): \delta$ 7.24-7.07 (6H, Ph), $6.53(\mathrm{~s}, 2 \mathrm{H}, \mathrm{NCH})$, $2.88\left(\mathrm{hpt}^{3} J_{\mathrm{H}-\mathrm{H}}=6.8,4 \mathrm{H}, \mathrm{CHCH}_{3}\right), 1.49\left(\mathrm{~d},{ }^{3} J_{\mathrm{H}-\mathrm{H}}=6.8,12 \mathrm{H}\right.$, $\left.\mathrm{CHCH}_{3}\right), 1.40(\mathrm{~m}, 3 \mathrm{H}, \mathrm{PCH}), 1.06\left(\mathrm{~d},{ }^{3} \mathrm{~J}_{\mathrm{H}-\mathrm{H}}=6.8,12 \mathrm{H}, \mathrm{CHCH}_{3}\right), 0.78$ $\left(\mathrm{dd},{ }^{3} J_{\mathrm{H}-\mathrm{H}}=13.4,{ }^{3} J_{\mathrm{H}-\mathrm{P}}=7.0,18 \mathrm{H}, \mathrm{PCHCH}_{3}\right),-8.81\left(\mathrm{~d},{ }^{2} J_{\mathrm{H}-\mathrm{P}}=9.7,6 \mathrm{H}\right.$, OsH). ${ }^{31} \mathrm{P}\left\{{ }^{1} \mathrm{H}\right\}$ NMR $\left(161.9 \mathrm{MHz}, \mathrm{C}_{6} \mathrm{D}_{6}, 298 \mathrm{~K}\right): \delta 56.5 .{ }^{13} \mathrm{C}\left\{{ }^{1} \mathrm{H}\right\}-$ APT NMR(75.4 MHz, $\left.\mathrm{C}_{6} \mathrm{D}_{6}, 298 \mathrm{~K}\right): \delta 177.5\left(\mathrm{~d},{ }^{2} J_{\mathrm{C}-\mathrm{P}}=56.6\right.$, OsC), $146.7,140.6,129.5,124.3$ (all s, Ph), $121.6(\mathrm{~s}, \mathrm{NCH}), 29.3(\mathrm{~s}$, $\left.\mathrm{CHCH}_{3}\right), 28.6\left(\mathrm{~d},{ }^{I} J_{\mathrm{C}-\mathrm{P}}=28.7, \mathrm{PCHCH}_{3}\right), 25.4\left(\mathrm{~s}, \mathrm{CHCH}_{3}\right), 23.0(\mathrm{~s}$, $\left.\mathrm{PCHCH}_{3}\right), 20.6\left(\mathrm{~s}, \mathrm{CHCH}_{3}\right)$

Preparation of $\mathrm{OsH}_{6}(\mathrm{IPr})\left(\mathrm{PPh}_{3}\right)$ (10). A yellow solution of $\mathrm{OsH}_{3}\left(\eta^{2}-\mathrm{H}_{2} \mathrm{BH}_{2}\right)(\mathrm{IPr})\left(\mathrm{PPh}_{3}\right)(\mathbf{8})(100 \mathrm{mg}, 0.116 \mathrm{mmol})$ in $5 \mathrm{~mL}$ of 2propanol was stirred for $4 \mathrm{~h}$ at room temperature. The resulting red solution was dried in vacuo. The residue was washed with cold pentane $(2 \times 1 \mathrm{~mL})$ to give a white solid which was dried in vacuo. Yield: $76 \mathrm{mg}(50 \%)$. Anal. Calcd for $\mathrm{C}_{45} \mathrm{H}_{58} \mathrm{~N}_{2} \mathrm{OsP}: \mathrm{C}, 63.72 ; \mathrm{H}, 6.89 ; \mathrm{N}$, 3.30. Found: $\mathrm{C}, 63.51 ; \mathrm{H}, 6.72 ; \mathrm{N}, 3.06$. HRMS (electrospray, $\mathrm{m} / \mathrm{z}$ ): $\mathrm{C}_{47} \mathrm{H}_{57} \mathrm{~N}_{3} \mathrm{OsP}$ [M - 4H+CH${ }_{3} \mathrm{CN}$ ]: 886.3903, found: 886.3904. IR (cm $\left.{ }^{1}\right): v(\mathrm{OsH}) 1868$ and $1944 \mathrm{~cm}^{-1} .{ }^{1} \mathrm{H}$ NMR $\left(300 \mathrm{MHz}, \mathrm{C}_{6} \mathrm{D}_{6}, 298 \mathrm{~K}\right): \delta$ 7.55-7.49 (5H, PPh), 7.33, 7.30, 7.19 (all d, ${ }^{2} J_{\mathrm{H}-\mathrm{H}}=7.6,6 \mathrm{H}, \mathrm{Ph}$ ), 6.99$6.88(10 \mathrm{H}, \mathrm{PPh}), 6.61(\mathrm{~s}, 2 \mathrm{H}, \mathrm{NCH}), 2.90\left(\mathrm{hpt},{ }^{2} J_{\mathrm{H}-\mathrm{H}}=6.8,4 \mathrm{H}\right.$, $\left.\mathrm{CHCH}_{3}\right), 1.40,1.10$ (both d, $\left.{ }^{2} J_{\mathrm{H}-\mathrm{H}}=6.8,24 \mathrm{H}, \mathrm{CHCH}_{3}\right),-7.37\left(\mathrm{~d},{ }^{2} J_{\mathrm{H}-\mathrm{P}}\right.$ $=9.8,6 \mathrm{H}, \mathrm{OsH}) \cdot{ }^{31} \mathrm{P}\left\{{ }^{1} \mathrm{H}\right\}$ NMR $\left(121.4 \mathrm{MHz}, \mathrm{C}_{6} \mathrm{D}_{6}, 298 \mathrm{~K}\right): \delta 25.5$ (s). ${ }^{13} \mathrm{C}\left\{{ }^{1} \mathrm{H}\right\}$-APT NMR $\left(75.4 \mathrm{MHz}, \mathrm{C}_{6} \mathrm{D}_{6}, 298 \mathrm{~K}\right): \delta 176.5$ (d, $J_{\mathrm{C}-\mathrm{P}}=$ 63.5, OsC), $146.7(\mathrm{~s}, \mathrm{Ph}), 142.0\left(\mathrm{~d}, J_{\mathrm{C}-\mathrm{P}}=50.3, \mathrm{C}_{i p s o} \mathrm{PPh}\right), 140.3(\mathrm{~s}$, $\mathrm{Ph}), 134.4\left(\mathrm{~d}, J_{\mathrm{C}-\mathrm{P}}=11.6, \mathrm{PPh}\right), 129.6(\mathrm{~s}, \mathrm{Ph}), 128.8(\mathrm{~s}, \mathrm{PPh}), 127.5(\mathrm{~d}$, $\left.J_{\mathrm{C}-\mathrm{P}}=9.9, \mathrm{PPh}\right), 124.5(\mathrm{~s}, \mathrm{Ph}), 121.7(\mathrm{~s}, \mathrm{NCH}), 29.3\left(\mathrm{~s}, \mathrm{CHCH}_{3}\right), 25.4$, 22.9 (both s, $\mathrm{CHCH}_{3}$ )

Preparation of $\mathrm{OsH}_{3}\left\{\mathrm{~K}^{2}-\mathrm{N}-\mathrm{C}-\left(\mathrm{NH}=\mathrm{CHC}_{6} \mathrm{H}_{4}\right)\right\}(\mathrm{IPr})\left(\mathrm{P}^{i} \mathrm{Pr}_{3}\right)$ (11). A pale yellow solution of $\mathrm{OsH}_{6}(\mathrm{IPr})\left(\mathrm{P}^{i} \mathrm{Pr}_{3}\right)(\mathbf{9})(100 \mathrm{mg}, 0.134 \mathrm{mmol})$ in $5 \mathrm{~mL}$ of toluene was treated with benzonitrile $(15 \mu \mathrm{L}, 0.147 \mathrm{mmol})$. The mixture was stirred for $1 \mathrm{~h}$ at reflux, and the resulting red solution was evaporated to dryness. The residue was washed with $2 \mathrm{~mL}$ of cold methanol obtaining an orange solid which was dried in vacuo. Yield: $83.2 \mathrm{mg}(73 \%)$. Anal. Calcd for $\mathrm{C}_{43} \mathrm{H}_{66} \mathrm{~N}_{3} \mathrm{OsP}$ : C, 61.03; $\mathrm{H}$, 7.86; N, 4.7. Found: C, 60.66; H, 7.76; N, 4.90. HRMS (electrospray $\mathrm{m} / \mathrm{z}): \mathrm{C}_{43} \mathrm{H}_{65} \mathrm{~N}_{3} \mathrm{OsP}: 846.4528$. Found: 846.4570. IR $\left(\mathrm{cm}^{-1}\right): v(\mathrm{NH})$ $3378 \mathrm{~cm}^{-1}, v(\mathrm{OsH}) 2103$ and $1931 \mathrm{~cm}^{-1}$. ${ }^{1} \mathrm{H}$ NMR (300 MHz, $\mathrm{C}_{6} \mathrm{D}_{6}$, $298 \mathrm{~K}): \delta 9.43(\mathrm{br}, 1 \mathrm{H}, \mathrm{N} H), 8.36\left(\mathrm{~d},{ }^{3} J_{\mathrm{H}-\mathrm{H}}=7.3,1 \mathrm{H}, \mathrm{CHPh}\right), 7.48$, 7.39 (both dd, $\left.{ }^{3} J_{\mathrm{H}-\mathrm{H}}=7.3,{ }^{4} J_{\mathrm{H}-\mathrm{H}}=1.6,2 \mathrm{H}, \mathrm{OsPh}\right), 7.31\left(\mathrm{t},{ }^{3} J_{\mathrm{H}-\mathrm{H}}=7.7\right.$, $2 \mathrm{H}, \mathrm{Ph}$ ), 7.22, 7.14 (both dd, $\left.{ }^{3} J_{\mathrm{H}-\mathrm{H}}=7.7,{ }^{4} J_{\mathrm{H}-\mathrm{H}}=1.6,4 \mathrm{H}, \mathrm{Ph}\right), 6.93$, 6.86 (both td, $\left.{ }^{3} J_{\mathrm{H}-\mathrm{H}}=7.3,{ }^{4} J_{\mathrm{H}-\mathrm{H}}=1.6,2 \mathrm{H}, \mathrm{OsPh}\right), 6.41(\mathrm{~s}, 2 \mathrm{H}, \mathrm{NCH})$, $3.36,2.65$ (both hpt, $\left.{ }^{3} J_{\mathrm{H}-\mathrm{H}}=6.8,4 \mathrm{H}, \mathrm{CHCH}\right), 1.53,\left(\mathrm{~d},{ }^{3} J_{\mathrm{H}-\mathrm{H}}=6.8\right.$, $6 \mathrm{H}, \mathrm{CHCH}_{3}$ ), 1.5 (hpt, ${ }^{2} J_{\mathrm{H}-\mathrm{P}}=7.2,3 \mathrm{H}, \mathrm{PCHCH}{ }_{3}$ ), 1.18, 1.07, 1.00 (all $\mathrm{d},{ }^{3} J_{\mathrm{H}-\mathrm{H}}=6.8,18 \mathrm{H}, \mathrm{CHCH}_{3}$ ), 0.84, 0.74 (both dd, ${ }^{3} J_{\mathrm{H}-\mathrm{H}}=12.1,{ }^{3} J_{\mathrm{H}-\mathrm{P}}$ $\left.=7.2,18 \mathrm{H}, \mathrm{PCHCH}_{3}\right),-6.77(\mathrm{br}, 1 \mathrm{H}, \mathrm{OsH}),-9.46(\mathrm{br}, 2 \mathrm{H}, \mathrm{OsH}) .{ }^{1} \mathrm{H}$ NMR $\left(400 \mathrm{MHz}, \mathrm{C}_{7} \mathrm{D}_{8}, 223 \mathrm{~K}\right): \delta 9.33\left(\mathrm{ddd},{ }^{3} J_{\mathrm{H}-\mathrm{P}}=9.3,{ }^{3} J_{\mathrm{H}-\mathrm{H}}=5.0\right.$, $\left.{ }^{3} J_{\mathrm{H}-\mathrm{H}}=5.0,1 \mathrm{H}, \mathrm{N} H\right),-6.68\left(\mathrm{ddd},{ }^{2} J_{\mathrm{H}-\mathrm{P}}=10.4,{ }^{2} J_{\mathrm{H}-\mathrm{H}}=5.0,{ }^{3} J_{\mathrm{H}-\mathrm{H}}=5.0\right.$, $1 \mathrm{H}, \mathrm{OsH}),-9.37\left(\mathrm{vt},{ }^{2} J_{\mathrm{H}-\mathrm{P}}=13.2,{ }^{2} J_{\mathrm{H}-\mathrm{H}}=13.2,1 \mathrm{H}, \mathrm{OsH}\right),-9.61(\mathrm{ddd}$, $\left.{ }^{2} J_{\mathrm{H}-\mathrm{P}}=26.2,{ }^{2} J_{\mathrm{H}-\mathrm{H}}=13.2,{ }^{2} J_{\mathrm{H}-\mathrm{H}}=5.0,1 \mathrm{H}, \mathrm{OsH}\right) .{ }^{31} \mathrm{P}$ NMR $(161.9$ MHz, $\left.\mathrm{C}_{6} \mathrm{D}_{6}, 298 \mathrm{~K}\right): \delta 19.7 .{ }^{13} \mathrm{C}\left\{{ }^{1} \mathrm{H}\right\}$-APT NMR, HSQC and HMBC $\left(75.4 \mathrm{MHz}, \mathrm{C}_{6} \mathrm{D}_{6}, 298 \mathrm{~K}\right): \delta 191.8\left(\mathrm{~d},{ }^{2} J_{\mathrm{C}-\mathrm{P}}=6.7, \mathrm{C}_{\mathrm{ips}}-\mathrm{OsPh}\right), 175.1$ $\left(\mathrm{d},{ }^{2} J_{\mathrm{C}-\mathrm{P}}=78.9, \mathrm{OsC}\right), 169.6(\mathrm{~s}, \mathrm{OsPh}), 147.4,147.0$ (both s, Ph), 146.9 (s, CHPh), 144.9 (s, OsPh), 140.3, 129.1 (both s, Ph), 128.8, 127.6 (both s, OsPh), 123.9, 123.4 (both s, Ph), 122.4 (s, NCH), 118.0 $(\mathrm{s}, \mathrm{OsPh}), 29.2,29.1$ (both $\left.\mathrm{s}, \mathrm{CHCH}_{3}\right), 27.5,\left(\mathrm{~d},{ }^{1} J_{\mathrm{C}-\mathrm{P}}=21.5\right.$, $\left.\mathrm{PCHCH}_{3}\right), 26.2,26.9,22.7,22.5\left(\right.$ all s, $\left.\mathrm{CHCH}_{3}\right), 20.0\left(\mathrm{~d},{ }^{2} J_{\mathrm{C}-\mathrm{P}}=17.5\right.$, $\mathrm{PCHCH}_{3}$ )

Preparation of $\mathrm{OsH}_{3}\left\{\kappa^{2}-N-C-\left(\mathrm{NH}=\mathrm{CHC}_{6} \mathrm{H}_{4}\right)\right\}(\mathrm{IPr})\left(\mathrm{PPh}_{3}\right)$ (12). A pale yellow solution of $\mathrm{OsH}_{6}(\operatorname{IPr})\left(\mathrm{PPh}_{3}\right)(\mathbf{1 0})(100 \mathrm{mg}, 0.118$ mmol) in $5 \mathrm{~mL}$ of toluene was treated with benzonitrile $(13.2 \mu \mathrm{L}$, $0.130 \mathrm{mmol})$. The mixture was stirred for $1 \mathrm{~h}$ at reflux, and the resulting red solution was evaporated to dryness. The residue was washed with $2 \mathrm{~mL}$ of cold methanol obtaining an orange solid which was dried in vacuo. Yield: $82.8 \mathrm{mg}(74 \%)$. Anal. Calcd for $\mathrm{C}_{52} \mathrm{H}_{60} \mathrm{~N}_{3} \mathrm{OsP}$ : C, 65.86; H, 6.38; N, 4.43. Found: C, 65.68; H, 6.39; N, 4.48. HRMS (electrospray m/z): $\mathrm{C}_{52} \mathrm{H}_{59} \mathrm{~N}_{3}$ OsP: 948.406 . Found: 948.412 . IR $\left(\mathrm{cm}^{-}\right.$ $\left.{ }^{1}\right): v(\mathrm{OsH}) 2114$ and $1977 \mathrm{~cm}^{-1}, v(\mathrm{NH}) 3373 \mathrm{~cm}^{-1} .{ }^{1} \mathrm{H}$ NMR (300 $\left.\mathrm{MHz}, \mathrm{C}_{6} \mathrm{D}_{6}, 298 \mathrm{~K}\right): \delta 9.04(\mathrm{br}, 1 \mathrm{H}, \mathrm{NH}), 7.99\left(\mathrm{~d},{ }^{3} J_{\mathrm{H}-\mathrm{H}}=7.5,1 \mathrm{H}\right.$, $\mathrm{CHPh}), 7.54-7.48(4 \mathrm{H}, \mathrm{OsPh}), 7.53-7.50(5 \mathrm{H}, \mathrm{PPh}), 7.42,7.33$ (both $\left.\mathrm{d},{ }^{3} J_{\mathrm{H}-\mathrm{H}}=7.7,4 \mathrm{H}, \mathrm{Ph}\right), 7.10-7.02(10 \mathrm{H}, \mathrm{PPh}), 7.03,6.80$ (both t, ${ }^{3} J_{\mathrm{H}-\mathrm{H}}$
$=7.2,2 \mathrm{H}, \mathrm{Ph}), 6.70(\mathrm{~s}, 2 \mathrm{H}, \mathrm{NCH}), 3.46,2.95$ (both hpt, ${ }^{3} J_{\mathrm{H}-\mathrm{H}}=6.8$, $\left.4 \mathrm{H}, \mathrm{CHCH}_{3}\right), 1.63,1.31,1.28,1.22\left(\right.$ all d, $\left.{ }^{3} J_{\mathrm{H}-\mathrm{H}}=6.7,24 \mathrm{H}, \mathrm{CHCH}_{3}\right)$, $-6.02(\mathrm{br}, 1 \mathrm{H}, \mathrm{OsH}),-8.59$ (br, $2 \mathrm{H}, \mathrm{OsH}) .{ }^{1} \mathrm{H}$ NMR $\left(400 \mathrm{MHz}, \mathrm{C}_{7} \mathrm{D}_{8}\right.$, $223 \mathrm{~K}): \delta 8.76\left(\mathrm{ddd},{ }^{3} J_{\mathrm{H}-\mathrm{P}}=9.6,{ }^{3} J_{\mathrm{H}-\mathrm{H}}=4.3,{ }^{3} J_{\mathrm{H}-\mathrm{H}}=4.3,1 \mathrm{H}, \mathrm{NH}\right)$, $5.79\left(\mathrm{ddd},{ }^{2} J_{\mathrm{H}-\mathrm{P}}=14.6,{ }^{2} J_{\mathrm{H}-\mathrm{H}}=4.3,{ }^{3} J_{\mathrm{H}-\mathrm{H}}=4.3,1 \mathrm{H}, \mathrm{OsH}\right),-8.72(\mathrm{vt}$, $\left.{ }^{2} J_{\mathrm{H}-\mathrm{P}}=11.8,{ }^{2} J_{\mathrm{H}-\mathrm{H}}=11.8,1 \mathrm{H}, \mathrm{OsH}\right),-8.96\left(\mathrm{ddd},{ }^{2} J_{\mathrm{H}-\mathrm{P}}=23.5,{ }^{2} J_{\mathrm{H}-\mathrm{H}}=\right.$ $\left.11.8,{ }^{2} J_{\mathrm{H}-\mathrm{H}}=4.3,1 \mathrm{H}, \mathrm{OsH}\right) .{ }^{31} \mathrm{P}$ NMR $\left(161.9 \mathrm{MHz}, \mathrm{C}_{6} \mathrm{D}_{6}, 298 \mathrm{~K}\right): \delta$ 21.8. ${ }^{13} \mathrm{C}\left\{{ }^{1} \mathrm{H}\right\}$-APT NMR, HSQC and HMBC $\left(75.4 \mathrm{MHz}, \mathrm{C}_{6} \mathrm{D}_{6}, 298\right.$ $\mathrm{K}): \delta 188.7\left(\mathrm{~d},{ }^{2} J_{\mathrm{C}-\mathrm{P}}=9.2, \mathrm{C}_{i p s o}-\mathrm{OsPh}\right), 175.5\left(\mathrm{~d},{ }^{2} J_{\mathrm{C}-\mathrm{P}}=94.8\right.$, OsC $)$, 147.2, 147.3 (both s, Ph), 146.7 (s, CHPh), 144.9 (s, OsPh), 140.1 (s, $\mathrm{Ph}), 138.5\left(\mathrm{~d},{ }^{1} J_{\mathrm{C}-\mathrm{P}}=41.6, \quad \mathrm{C}_{i p s o}-\mathrm{PPh}\right), 134.3\left(\mathrm{~d}, J_{\mathrm{C}-\mathrm{P}}=10.6, \mathrm{PPh}\right)$, $129.2,128.5,128.2,128.1($ all s, OsPh $), 127.1\left(\mathrm{~d}, J_{\mathrm{C}-\mathrm{P}}=8.9, \mathrm{PPh}\right)$ 123.9, 123.6 (both s,Ph), 122.4 (s, NCH), $118.2(\mathrm{~s}, \mathrm{Ph}), 29.3,29.2$ (both s, $\mathrm{CHCH}_{3}$ ), 26.1, 25.9, 22.6, 22.3 (both s, $\mathrm{CHCH}_{3}$ ).

Structural Analysis of Complexes 6, 8, and 11. X-ray data were collected for the complexes on a Bruker Smart APEX or APEX Duo diffractometers equipped with a normal focus, $2.4 \mathrm{~kW}$ sealed tube source (Mo radiation, $\lambda=0.71073 \AA$ ) operating at $50 \mathrm{kV}$ and $40 \mathrm{~mA}$ (8) or $30 \mathrm{~mA}$ (6 and 11). Data were collected over the complete sphere. Each frame exposure time was $10 \mathrm{~s}$ covering $0.3^{\circ}$ in $\omega$. Data were corrected for absorption by using a multiscan method applied with the SADABS program. ${ }^{47}$ The structures were solved by Patterson or direct methods and refined by full-matrix least squares on $\mathrm{F}^{2}$ with SHELXL97, ${ }^{48}$ including isotropic and subsequently anisotropic displacement parameters. The hydrogen atoms (except hydrides) were observed in the least Fourier Maps or calculated, and refined freely or using a restricted riding model. Hydrides were observed in the last cycles of refinement and refined too close to metals, so a restricted refinement model was used.

Crystal data for 6: $\mathrm{C}_{36} \mathrm{H}_{60} \mathrm{ClN}_{2} \mathrm{OsP}, \mathrm{M}_{\mathrm{W}} 777.48$, red, irregular block $(0.17 \times 0.14 \times 0.14)$, orthorhombic, space group $\mathrm{P} 22_{1} 2_{1} 2_{1}$, $a$ : $12.8306(7) \AA \AA, b: 14.7159(8) \AA, c: 20.3680(11) \AA, V=3845.8(4) \AA^{3}, Z$ $=4, Z^{\prime}=1, \mathrm{D}_{\text {calc }}: 1.343 \mathrm{~g} \mathrm{~cm}^{-3}, \mathrm{~F}(000): 1592, \mathrm{~T}=100(2) \mathrm{K}, \mu 3.451$ $\mathrm{mm}^{-1} .34023$ measured reflections $\left(2 \theta: 3-58^{\circ}, \omega\right.$ scans $\left.0.3^{\circ}\right), 9201$ unique $\left(\mathrm{R}_{\text {int }}=0.0398\right)$; min./max. transm. Factors $0.699 / 0.862$. Final agreement factors were $\mathrm{R}^{1}=0.0390(8683$ observed reflections, $\mathrm{I}>$ $2 \sigma(\mathrm{I}))$ and $\mathrm{wR}^{2}=0.0910 ;$ Flack parameter 0.002(8); data/restraints/parameters 9201/3/395; $\mathrm{GoF}=1.077$. Largest peak and hole 3.967 (close to osmium atom) and $-1.114 \mathrm{e} / \AA^{3}$.

Crystal data for 8: $\mathrm{C}_{45} \mathrm{H}_{58} \mathrm{BN}_{2} \mathrm{OsP}, \mathrm{M}_{\mathrm{W}}$ 858.91, yellow, irregular block $(0.19 \times 0.16 \times 0.12)$, monoclinic, space group $\mathrm{C} 2 / \mathrm{c}, a$ : 21.4514(17) $\AA, b: 10.3031(8) \AA, c: 38.022(3) \AA, \beta: 100.2510(10)^{\circ}, V$ $=8269.4(11) \AA^{3}, Z=8, Z^{\prime}=1, D_{\text {calc }}: 1.380 \mathrm{~g} \mathrm{~cm}^{-3}, \mathrm{~F}(000): 3504, \mathrm{~T}=$ $100(2) \mathrm{K}, \mu 3.155 \mathrm{~mm}^{-1}$. 48295 measured reflections $\left(2 \theta: 3-58^{\circ}\right.$, $\omega$ scans $\left.0.3^{\circ}\right), 9839$ unique $\left(\mathrm{R}_{\text {int }}=0.0610\right)$; min./max. transm. Factors $0.714 / 0.862$. Final agreement factors were $\mathrm{R}^{1}=0.0399$ (7899 observed reflections, I $>2 \sigma(\mathrm{I}))$ and $\mathrm{wR}^{2}=0.0878$; data/restraints/parameters 9839/7/482; GoF $=1.022$. Largest peak and hole 1.421 (close to osmium atom) and $-1.178 \mathrm{e} / \AA^{3}$.

Crystal data for 11: $\mathrm{C}_{43} \mathrm{H}_{66} \mathrm{~N}_{3} \mathrm{OsP}, \mathrm{M}_{\mathrm{W}} 846.16$, red, irregular block $(0.23 \times 0.12 \times 0.01)$, monoclinic, space group $\mathrm{P} 2_{1} / \mathrm{n}, a: 10.8632(19)$ $\AA, b: 20.893(4) \AA, c: 18.388(3) \AA, \beta: 92.917(3)^{\circ}, V=4168.0(13) \AA^{3}$, $Z=4, Z^{\prime}=1, \mathrm{D}_{\text {calc }}: 1.348 \mathrm{~g} \mathrm{~cm}^{-3}, \mathrm{~F}(000): 1744, \mathrm{~T}=173(2) \mathrm{K}, \mu 3.129$ $\left.\mathrm{mm}^{-1}\right) .66798$ measured reflections $\left(2 \theta: 3-58^{\circ}, \omega\right.$ scans $\left.0.3^{\circ}\right), 11045$ unique $\left(\mathrm{R}_{\text {int }}=0.0528\right)$; min./max. transm. Factors $0.714 / 0.862$. Final agreement factors were $\mathrm{R}^{1}=0.0312(8563$ observed reflections, $\mathrm{I}>$ $2 \sigma(\mathrm{I}))$ and $\mathrm{wR}^{2}=0.0792 ;$ data/restraints/parameters $11045 / 3 / 459$; $\mathrm{GoF}=1.025$. Largest peak and hole 1.869 and $-0.470 \mathrm{e} / \AA^{3}$.

\section{ASSOCIATED CONTENT}

\section{Supporting Information}

Cartesian coordinates and energies of all species discussed in the text, and CIF crystallography data for compounds $\mathbf{6}, \mathbf{8}$, and $\mathbf{1 1}$. This material is available free of charge via the Internet at http://pubs.acs.org.

\section{AUTHOR INFORMATION}

Corresponding Author 
*E-mail: maester@unizar.es (M.A.E.)

\section{ACKNOWLEDGMENT}

Financial support from the Spanish MINECO (Projects CTQ201452799-P, CTQ2013-44303-P, Red de Excelencia Consolider CTQ2014-51912-REDC), the DGA (E35) and the European Social Fund (FSE) and FEDER is acknowledged. J. J. F. acknowledges support via a pre-doctoral fellowship from the DGA.

\section{REFERENCES}

(1) (a) Denney, M. C.; Pons, V.; Hebden, T. J.; Heinekey, D. M.; Goldberg, K. I. J. Am. Chem. Soc.2006, 128, 12048-12049. (b) Paul, A.; Musgrave, C. B. Angew. Chem. Int. Ed.2007, 46, 8153-8156. (c) St John, A.; Goldberg, K. I.; Heinekey, D. M. Top. Organometal. Chem.2013, 40, 271-287. (d) Esteruelas, M. A.; López, A. M.; Mora, M.; Oñate, E. ACS Catal.2015, 5, 187-191.

(2) (a) Choi, J.; MacArthur, A. H. R.; Brookhart, M.; Goldman, A. S. Chem. Rev. 2011, 111, 1761-1779. (b) Haibach, M. C.; Kundu, S.; Brookhart, M.; Goldman, A. S. Acc. Chem. Res. 2012, 45, 947-958.

(3) (a) Esteruelas, M. A.; García-Raboso, J.; Oliván, M. Inorg. Chem.2012, 51, 9522-9528. (b) Esteruelas, M. A.; García-Raboso, J.; Oliván, M.; Oñate, E. Inorg. Chem.2012, 51, 5975-5984. (c) Casarrubios, L.; Esteruelas, M. A.; Larramona, C.; Muntaner, J. G.; Oliván, M.; Oñate, E.; Sierra, M. A. Organometallics2014, 33, 1820-1833.

(4) (a) Tsai, A. C.; Xia, C. J.; Esteruelas, M. A. Patten Appl. US201314075653, 2013. (b) Tsai, A. C.; Xia, C. J.; Esteruelas, M. A.; Oñate, E.; Bolaño, T.; Palacios, A. U. Pattent Appl. US201314075527, 2013. (c) Xia, C. J.; Tsai, A. C.; Eguillor, B.; Esteruelas, M. A.; Gómez, R.; Oliván, M.; Oñate, E. Pattent Appl. US201313950591, 2013. (d) Alabau, R. G.; Eguillor, B.; Esler, J.; Esteruelas, M. A.; Oliván, M.; Oñate, E.; Tsai, J. Y.; Xia, C. J. Organometallics 2014, 33, 5582-5596.

(5) Simoes, J. A. M.; Beauchamp, J. L. Chem. Rev.1990, 90, 629688 .

(6) Ortuno, M. A.; Vidossich, P.; Conejero, S.; Lledós, A. Angew. Chem. Int. Ed.2014, 53, 14158-14161.

(7) Maseras, F.; Lledós, A.; Clot, E.; Eisenstein, O. Chem. Rev.2000, 100, 601-636. 48.

(8) Hlatky, G. G.; Crabtree, R. H. Coord. Chem. Rev.1985, 65, 1-

(9) (a) Poyatos, M.; Mata, J. A.; Peris, E. Chem. Rev.2009, 109, 3677-3707. (b) Schuster, O.; Yang, L. R.; Raubenheimer, H. G.; Albrecht, M. Chem. Rev. 2009, 109, 3445-3478.

(10) Díez-González, S.; Marion, N.; Nolan, S. P. Chem. Rev.2009, 109, 3612-3676

(11) (a) Mercs, L.; Albrecht, M. Chem. Soc. Rev.2010, 39, 19031912. (b) Visbal, R.; Gimeno, M. C. Chem. Soc. Rev.2014, 43, 35513574.

(12) (a) Baya, M.; Eguillor, B.; Esteruelas, M. A.; Oliván, M.; Oñate, E. Organometallics 2007, 26, 6556-6563. (b) Eguillor, B.; Esteruelas, M. A.; Oliván, M.; Puerta, M. Organometallics2008, 27, 445-450. (c) Dobereiner, G. E.; Nova, A.; Schley, N. D.; Hazari, N.; Miller, S. J.; Eisenstein, O.; Crabtree, R. H. J. Am. Chem. Soc.2011, 133, 7547-7562. (d) Eguillor, B.; Esteruelas, M. A.; García-Raboso, J.; Oliván, M.; Oñate, E.; Pastor, I. M.; Peñafiel, I.; Yus, M. Organometallics2011, 30, 1658-1667. (e) Bolaño, T.; Esteruelas, M. A.; Fernández, I.; Oñate, E.; Palacios, A.; Tsai, J. Y.; Xia, C. J. Organometallics 2015, 34, 778-789.

(13) (a) Jones, A. L.; McGrady, G. S.; Sirsch, P.; Steed, J. W. Chem. Commun.2005, 5994-5996. (b) Castarlenas, R.; Esteruelas, M. A.; Oñate, E. Organometallics 2008, 27, 3240-3247. (c) Mai, V. H.; Kuzmina, L. G.; Churakov, A. V.; Korobkov, I.; Howard, J. A. K.; Nikonov, G. I. Dalton Trans. 2016, 45, 208-215.

(14) Burling, S.; Haller, L. J. L.; Mas-Marza, E.; Moreno, A.; Macgregor, S. A.; Mahon, M. F.; Pregosin, P. S.; Whittlesey, M. K. Chem. Eur. J.2009, 15, 10912-10923.

(15) Rivada-Wheelaghan, O.; Roselló-Merino, M.; Ortuño, M. A.; Vidossich, P.; Gutiérrez-Puebla, E.; lledós, A.; Conejero, S. Inorg. Chem. 2014, 53, 2457-2568.
(16) Giunta, D.; Holscher, M.; Lehmann, C. W.; Mynott, R.; Wirtz, C.; Leitner, W. Adv. Synth. Catal.2003, 345, 1139-1145.

(17) See for example:(a) Scott, N. M.; Pons, V. P; Stevens, E. D. Heinekey, D. M.; Nolan, S. P. Angew. Chem. Int. Ed.2005, 44, 2512 2515. (b) Fantasia, S.; Egbert, J. D.; Jurčík, V.; Cazin, C. S. J.; Jacobsen, H.; Cavallo, L.; Heinekey, D. M.; Nolan, S. P. Angew. Chem. Int. Ed., 2009, 48, 5182-5186. (c) Tang, C. Y.; Thompson, A. L.; Aldridge, S.; J. Am. Chem. Soc., 2010, 132, 10578-10591.

(18) (a) Reade, S. P.; Nama, D.; Mahon, M. F.; Pregosin, P. S.; Whittlesey, M. K. Organometallics 2007, 26, 3484-3491. (b) Reade, S. P.; Mahon, M. F.; Whittlesey, M. K. J. Am. Chem. Soc.2009, 131, 1847-1861.

(19) (a) Esteruelas, M. A.; Herrero, J.; López, A. M.; Oliván, M. Organometallics 2001，20, 3202-3205. (b) Varela-Fernández, A.; García-Yebra, C.; Varela, J. A.; Esteruelas, M. A.; Saá, C. Angew. Chem. Int. Ed.2010, 49, 4278-4281. (c) Buil, M. L.; Esteruelas, M. A.; Herrero, J.; Izquierdo, S.; Pastor, I. M.; Yus, M. ACS Catal.2013, 3, 2072-2075. (d) Álvarez-Pérez, A.; González-Rodríguez, C.; GarcíaYebra, C.; Varela, J. A.; Oñate, E.; Esteruelas, M. A.; Saá, C. Angew. Chem. Int. Ed.2015, 54, 13357-13361.

(20) (a) Castarlenas, R.; Esteruelas, M. A.; Oñate, E. Organometallics 2005, 24, 4343-4346. (b) Buil, M. L.; Castarlenas, R.; Esteruelas, M. A.; Izquierdo, S.; Lalrempuia, R.; Oñate, E. Organometallics 2010, 29, 876-882.

(21) Castarlenas, R.; Esteruelas, M. A.; Oñate, E. Organometallics 2007, 26, 2129-2132.

(22) Buil, M. L.; Cardo, J. J. F.; Esteruelas, M. A.; Fernández, I.; Oñate, E. Organometallics 2014, 33, 2689-2692.

(23) Buil, M. L.; Cardo, J. J. F.; Esteruelas, M. A.; Fernández, I.; Oñate, E. Organometallics 2015, 34, 547-550.

(24) Esteruelas, M. A.; Fernández-Alvarez, F. J.; López, A. M.; Mora, M.; Oñate, E. J. Am. Chem. Soc. 2010, 132, 5600-5601.

(25) Gusev, D. G.; Kuhlman, R.; Sini, G.; Eisenstein, O.; Caulton, K. G. J. Am. Chem. Soc.1994, 116, 2685-2686.

(26) Kuhlman, R.; Clot, E.; Leforestier, C.; Streib, W. E.; Eisenstein, O.; Caulton, K. G. J. Am. Chem. Soc.1997, 119, 1015310169 .

(27) Esteruelas, M. A.; García-Raboso, J.; Oliván, M. Organometallics 2011, 30, 3844-3852.

(28) Esteruelas, M. A.; Fernández, I.; López, A. M.; Mora, M.; Oñate, E. Organometallics2012, 31, 4646-4649.

(29) Werner, H.; Esteruelas, M. A.; Meyer, U.; Wrackmeyer, B Chem. Ber.1987, 120, 11-15.

(30) Esteruelas, M. A.; López, A. M.; Mora, M.; Oñate, E. Organometallics 2015, 34, 941-946.

(31) (a) Esteruelas, M. A.; Jean, Y.; Lledós, A.; Oro, L. A.; Ruiz, N.; Volatron, F. Inorg. Chem.1994, 33, 3609-3611. (b) Demachy, I.; Esteruelas, M. A.; Jean, Y.; Lledós, A.; Maseras, F.; Oro, L. A.; Valero, C.; Volatron, F. J. Am. Chem. Soc. 1996, 118, 8388-8394.

(32) Frost, P. W.; Howard, J. A. K.; Spencer, J. L. J Chem. Soc. Chem. Comm.1984, 1362-1363.

(33) (a) Duckett, S. B.; Lowe, J. C.; Lowe, J. P.; Mawby, R. J. Dalton Trans.2004, 3788-3797. (b) Duckett, S. B.; Lowe, J. P.; Mawby, R. J. Dalton Trans.2006, 2661-2670.

(34) Chamberlain, B.; Duckett, S. B.; Lowe, J. P.; Mawby, R. J.; Stott, J. C. Dalton Trans. 2003, 2603-2614.

(35) Alós, J.; Bolaño, T.; Esteruelas, M. A.; Oliván, M.; Oñate, E.; Valencia, M. Inorg. Chem.2013, 52, 6199-6213.

(36) (a) Douglas, P. G.; Shaw, B. L. J Chem Soc A1970, 334-\&. (b) Connelly, N. G.; Howard, J. A. K.; Spencer, J. L.; Woodley, P. K. J. Chem. Soc. Dalton.1984, 2003-2009. (c) Aracama, M.; Esteruelas, M. A.; Lahoz, F. J.; Lopez, J. A.; Meyer, U.; Oro, L. A.; Werner, H. Inorg. Chem.1991, 30, 288-293. (d) Richter, B.; Werner, H. Eur J Inorg. Chem. 2009, 4625-4628.

(37) Howard, J. A. K.; Johnson, O.; Koetzle, T. F.; Spencer, J. L. Inorg. Chem.1987, 26, 2930-2933.

(38) (a) Gallop, M. A.; Rickard, C. E. F.; Roper, W. R. J. Organomet. Chem.1990, 395, 333-340. (b) Werner, H.; Daniel, T.; Braun, T.; Nurnberg, O. J. Organomet. Chem.1994, 480, 145-153. (c) Esteruelas, M. A.; Lahoz, F. J.; López, A. M.; Oñate, E.; Oro, L. A. Organometallics 1995, 14, 2496-2500. (d) Barea, G.; Esteruelas, M. 
A.; Lledós, A.; López, A. M.; Oñate, E.; Tolosa, J. I. Organometallics1998, 17, 4065-4076. (e) Esteruelas, M. A.; Gutiérrez-Puebla, E.; López, A. M.; Oñate, E.; Tolosa, J. I. Organometallics 2000, 19, 275-284. (f) Esteruelas, M. A.; Lledós, A.; Oliván, M.; Oñate, E.; Tajada, M. A.; Ujaque, G. Organometallics 2003, 22, 3753-3765.

(39) Gaussian 09, Revision B.01, Frisch, M. J.; Trucks, G. W.; Schlegel, H. B.; Scuseria, G. E.; Robb, M. A.; Cheeseman, J. R.; Scalmani, G.; Barone, V.; Mennucci, B.; Petersson, G. A.; Nakatsuji, H.; Caricato, M.; Li, X.; Hratchian, H. P.; Izmaylov, A. F.; Bloino, J.; Zheng, G.; Sonnenberg, J. L.; Hada, M.; Ehara, M.; Toyota, K.; Fukuda, R.; Hasegawa, J.; Ishida, M.; Nakajima, T.; Honda, Y.; Kitao, O.; Nakai, H.; Vreven, T.; Montgomery, J. A., Jr.; Peralta, J. E.; Ogliaro, F.; Bearpark, M.; Heyd, J. J.; Brothers, E.; Kudin, K. N.; Staroverov, V. N.; Kobayashi, R.; Normand, J.; Raghavachari, K.; Rendell, A.; Burant, J. C.; Iyengar, S. S.; Tomasi, J.; Cossi, M.; Rega, N.; Millam, N. J.; Klene, M.; Knox, J. E.; Cross, J. B.; Bakken, V.; Adamo, C.; Jaramillo, J.; Gomperts, R.; Stratmann, R. E.; Yazyev, O.; Austin, A. J.; Cammi, R.; Pomelli, C.; Ochterski, J. W.; Martin, R. L.; Morokuma, K.; Zakrzewski, V. G.; Voth, G. A.; Salvador, P.; Dannenberg, J. J.; Dapprich, S.; Daniels, A. D.; Farkas, Ö.; Foresman, J. B.; Ortiz, J. V.; Cioslowski, J.; Fox, D. J. Gaussian, Inc., Wallingford CT, 2009.

(40) (a) Becke, A. D. Phys. Rev. A1988, 38, 3098-3100. (b) Perdew, J. P. Phys. Rev. B1986, 33, 8822-8824.

(41) (a) Weigend, F.; Häser, M.; Patzelt, H.; Ahlrichs, R. Chem. Phys. Lett. 1998, 294, 143-152. (b) Weigend, F.; Ahlrichs, R. Phys. Chem. Chem. Phys. 2005, 7, 3297-3305.

(42) Schäfer, A.; Horn, H.; Ahlrichs, R. J. Chem. Phys. 1992, 97, 2571-2577.

(43) (a) Foster, J. P.; Weinhold, F. J. Am. Chem. Soc. 1980, 102, 7211-7218. (b) Reed, A. E.; Weinhold, F. J. Chem. Phys. 1985, 83, 1736-1740. (c) Reed, A. E.; Weinstock, R. B.; Weinhold, F. J. Chem. Phys. 1985, 83, 735-746. (d) Reed, A. E.; Curtiss, L. A.; Weinhold, F. Chem. Rev. 1988, 88, 899-926.

(44) (a) Huzinaga, S.; Miguel, B. Chem. Phys. Lett. 1990, 175, 289-291. (b) Huzinaga, S.; Klobukowski, M. Chem. Phys. Lett. 1993, 212, 260-264

(45) Cabeza, J. A.; van der Maelen, J. F.; García-Granda, S. Organometallics2009, 28, 3666-3672 and references therein.

(46) Keith, T. A. AIMAll, 2010, http://tkgristmill.com

(47) Blessing, R. H. ActaCrystallogr. 1995, A51, 33. SADABS: Area-detector absorption correction; Bruker-AXS, Madison, WI, 1996.

(48) SHELXTL Package v.6.14; Bruker-AXS, Madison, WI, 2000. Sheldrick, G. M. Acta Cryst. 2008, A64, 112-122. 


\section{For Table of Contents Only}

\section{SYNOPSIS.}

The borylation of the metal-carbon triple bond of the phosphine-osmium-NHC, five coordinate, hydride-alkylidyne complexes $\left[\mathrm{OsHCl}(\equiv \mathrm{CPh})(\mathrm{IPr})\left(\mathrm{PR}_{3}\right)\right] \mathrm{OTf}\left(\mathrm{PR}_{3}=\mathrm{P}^{i} \mathrm{Pr}_{3}, \mathrm{PPh}_{3}\right)$ with the tetrahydridoborate anion under alcoholysis conditions is the key to access polyhydrides stabilized by phosphine-osmium-NHC basements. Thus, the first compounds of four different types of mixed polyhydrides are reported, including : $\mathrm{OsH}_{3} \mathrm{Cl}(\mathrm{NHC})\left(\mathrm{P}^{i} \mathrm{Pr}_{3}\right), \quad \mathrm{OsH}_{3}\left(\kappa^{2}-\mathrm{H}_{2} \mathrm{BH}_{2}\right)(\mathrm{NHC})\left(\mathrm{PR}_{3}\right), \quad \mathrm{OsH}_{6}(\mathrm{NHC})\left(\mathrm{PR}_{3}\right), \quad$ and $\mathrm{OsH}_{3}(\mathrm{XY})(\mathrm{NHC})\left(\mathrm{PR}_{3}\right)$.

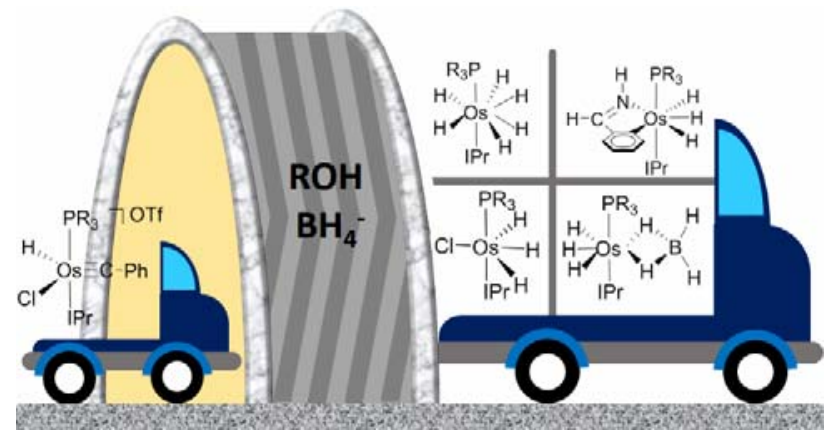

